
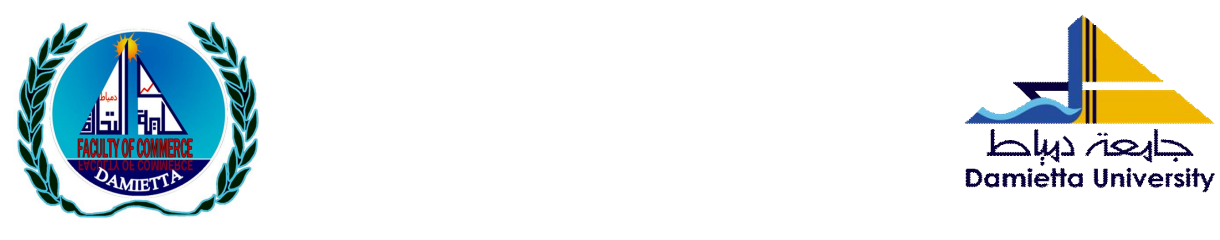

\title{
The Impact of Joint Audit on Audit- Planning Quality - A Field Study
}

\author{
Prepared 6y \\ Dr. Yasser Mohamed \\ Dr. Hany Mohamed Aziz \\ Abdel-Aziz Samra \\ Elzahar \\ Professor of Auditing, \\ Assistant professor in Accounting, \\ Faculty of Commerce, Damietta \\ University \\ Faculty of Commerce, Damietta \\ University \\ Hadeer Musaad Ahmed Fayed \\ Demonstrator, Accounting Department, \\ Faculty of Commerce, Damietta University
}

Scientific Journal for Financial and Commercial Studies and Researches (SIFCSR)

Faculty of Commerce - Damietta University

Vol.3, $\mathcal{N}$ o.1, Part 1., January 2022

APA Citation:

Samra, Y.M.A.; Elzahar, H. M.A. and Fayed, H.M.A. (2022). The Impact of Joint Audit on Audit Planning Quality: A Field Study, Scientific Journal for Financial and Commercial Studies and Research, Faculty of Commerce, Damietta University, 3(1)1.pp. 35-82

Website: $\underline{\text { https://cfdj.journals.ekb.eg/ }}$ 
Scientific Journal for Financial and Commercial Studies and Researches

(SJFCSR) Faculty of Commerce - Damietta University

\title{
The Impact of Joint Audit on Audit-Planning Quality - A Field Study
}

\author{
Dr. Yasser Mohamed Abdel-Aziz \\ Samra
}

\author{
Dr. Hany Mohamed Aziz \\ Elzahar
}

Hadeer Musaad Ahmed Fayed

\begin{abstract}
In the Egyptian environment, joint audit is implemented voluntary and mandatory before the European Commission issues its report in 2010. It is implemented voluntary for first time in 1981 for the Egyptian Stock companies, insurance companies, and factoring companies. While, banks have been obligated to implement joint audit since 2003. In addition to mortgage finance companies, fund-raising companies, investor protection fund, investment funds, and depository companies and central registration must designate at least two independent auditors. The purpose of this paper is to investigate the impact of joint audit on audit planning quality in the Egyptian environment. By examining whether joint audit can affect on the initial audit planning, the comprehensive audit strategy, and the overall audit plan and program, as proxies for audit planning quality. To test our hypotheses, we use a sample of 400 professional auditors from different-sized auditing firms and academics from different Egyptian universities. The results of our multiple regression analyses show that joint audit has a significant positive impact on the initial audit planning. Moreover, we find that joint audit has a significant positive impact on the comprehensive audit strategy. We also find joint audit has a significant positive impact on the overall audit plan and program. The results of the additional analyses show that the majority of the respondents' opinions (93\%) support the application of voluntary joint audit for all companies and (89\%) support if one of the two appointed auditors is a non-big 4 auditor.
\end{abstract}

Keywords: Joint audit, Audit planning quality, initial audit planning, comprehensive audit strategy, overall audit plan and program. 
Samra, Y.M.A. \& Elzahar, H. M.A. \& Fayed, H.M.A.

\section{Introduction}

The objective of this paper is to investigate the impact of joint audit on audit planning quality in the Egyptian environment. One of the most important mechanisms proposed by the European Commission for improving audit firms' ability to detect and prevent corporate bankruptcies, frauds and failures, was the practice of joint audit (EC, 2010). Unlike single audit, which is the norm in most countries around the world, some countries require, while others permit, financial statements to be audited by more than one audit firm (Al-Hadi et al., 2017). Where, joint audit is considered an advanced form of judging financial statements, improving auditor's independence, and facing the client's management pressures (Lobo et al., 2014). As it allows the possibility of the participation of two independent auditors from different audit firms, benefiting from their diverse experience. In such a way that involves: making the client acceptance decision jointly, developing the comprehensive audit strategy jointly, and developing the audit plan jointly. In addition to performing the audit work jointly, making periodic cross reviews and mutual quality controls, issuing and signing a single audit report; and bearing joint liability in case of audit failure (Zerni et al., 2012; Alanezi et al., 2012).

In contrast to majority of accounting studies focusing on the impact of joint audit on the final stages of audit process like audit quality, issuance of the report, and financial reporting quality (e.g., Ittonen \& Tronnes, 2015; Bisogno \& De luca, 2016; Lobo et al., 2017; Quick \& Schmidt, 2018; Barghathi et al., 2020). We concentrate on audit planning (the first stage and the cornerstone of the audit) (IAASB, ISA 300, 2017), for many reasons; first, audit planning is important to ensure due professional care is exercised over the audit. Second, it is ensuring potential problems are identified and resolved on a timely basis in order to perform the audit efficiently and effectively. Third, it is ensuring the tasks are distributed appropriately on the assistants in order to facilitate the guidance, supervision, examination, and coordination of their work by the auditors and other experts. Consequently, audit planning is the most important stage of the audit because of its important reflections on the rest stages of the audit (Gray \& Manso, 2005; Ratanasongtham \& Ussahawanitchakit, 2015; Backof et al., 2018). Phagaphasvivat (2000) 
Scientific Journal for Financial and Commercial Studies and Researches

(SJFCSR) Faculty of Commerce - Damietta University

indicated that the auditors with greater audit planning are likely to generate more efficient audits that encourage them to maintain the competitive and their clients. Although the issue of audit planning quality has not attracted considerable regulatory and academic interest worldwide. Given that external auditing serves as a monitoring device (Alsadoun \& Aljabr, 2014), the auditor's failure to properly plan the audit can manifest as lower audit quality, higher litigation risk, and loss of reputation (Laux \& Newman, 2010). As happened in the Enron \& World Companies scandal and the failure of the auditing firm Arthur Andersen have all cast doubt on audit quality, and market concentration (Okaro et al., 2018).

Prior research on joint audit generally finds that: (i) joint audit can improve auditor independence by providing further opportunities to express conflicting opinions and it can weak the economic bonding between the auditor and the client (Ittonen \& Tronnes, 2015 Abdelmoula \& Affes, 2019), although Zerni et al. (2012) find evidence that joint audit can lead to the problem of "Free Riding". (ii) Joint audit can reduce audit market concentration by assisting small and mid-tier firms to acquire major clients, providing them with the experience, and allowing them to invest as needed to grow their presence in the large company market (Lobo et al., 2014; Holm \& Thinggaard, 2014; Kermiche \& Piot, 2018). (iii) Joint audit increases the level of accounting conservatism, which reduce the earnings management practices, especially on companies that apply joint audit voluntarily (Galy, 2018). Finally, (iv) joint audit increases the future firm value by increasing the shareholders' confidence, which help to create additional investment opportunities, increasing the enterprise's stock prices, and reducing the restatement of financial statements (Baldauf \& Steckel, 2012). Consequently, we choose audit-planning quality as we argue that the reason for the positive impacts of joint audit on the final stages of audit may be due to its positive impact on audit planning procedures.

Moreover, many studies have indicated some advantages that can be gained from a joint audit during planning the audit without practical verification of this effect. For example, Baldauf \& Steckel (2012); Lobo et al. (2017) indicate that the existence of two audit firms can provide a greater opportunity to choose a more experienced and efficient team that 
Samra, Y.M.A. \& Elzahar, H. M.A. \& Fayed, H.M.A.

can work together to develop an integrated audit plan in order to achieve the highest possible level of quality. Therefore, joint audit may be one of the proposals to reduce the failure of audit planning. Lin et al. (2014) argue that the participation of two auditors in developing the overall audit strategy means the existence of a large amount of expertise and possibilities available to each auditor. Therefore, each of them may assess the tasks assigned to him at the highest possible level of quality. Ittonen \& Trønnes (2015); Ruwished (2016) point out that joint audit provides the advantage of mutual control and supervision during the development of audit program, which ensures setting the appropriate audit procedures in accordance with Generally Accepted Auditing standards (GAAS).

Therefore, in order to provide direct answer to this dilemma, we use a sample of professional auditors and academics from the Egyptian environment where Egypt is one of the few countries, which has been implementing joint audit voluntary and mandatory before the European Commission issues its report in 2010. For example, in the Egyptian environment, joint audit is implemented voluntary in Egypt for first time in 1981, when the Companies Law issued Law No. 159 for1981, which states that listed companies in the Egyptian Stock Exchange must designate at least one auditor (Abdel-Qawi, 2017) as well as insurance companies, and factoring companies. However, this concept has become mandatory in Egypt for first time in 2003, when the Central Bank issued Law No. 88/2003, stating that banks listed on the Egyptian stock exchange must have at least two independent auditors who have no dependent link with each other (El-Assy, 2015). In addition, many Egyptian prior studies (e.g., Metwally, 2013; El-Assy, 2015; Saleh, 2015; Youssef, 2015; El-Dyasty, 2017) examined the effect of the joint audit on many variables (e.g., audit quality, financial reporting quality, and earnings quality), reached to positive results. Hence, it is a fertile environment for studying the subject under study. Since audit planning quality consists of specific and studied steps derived from the practical experience of auditors, which is called "audit-planning requirements" (Lin \& Fraser, 2003; Peecher et al., 2007). These requirements are divided into three main requirements (initial audit planning, a comprehensive audit strategy, and an overall audit plan), each of them 
has several sub-requirements. We use these requirements as proxies for audit planning quality. Whether the provision of joint audit improves the audit planning quality, therefore, is an important research topic. By documenting a beneficial effect of joint audit in terms of improving the audit planning procedures, we contribute to the joint audit and audit planning literature. Finally, to the best of our knowledge, there is no study, whether foreign or Arab, that studied the impact of joint audit on audit planning quality. Therefore, this paper presents the first field study in this topic.

Using sample opinions of 400 professional auditors and academics related to auditing in Egypt during the period October 2020 to March 2021, we investigate the effecting role of joint audit on audit planning quality in the Egyptian environment. We specially focus on audit planning quality without addressing the rest of the audit stages (implementation, documentation, and issuance the report) given the fact this audit planning is seen as the backbone of the auditing process and the objective basis for the outputs' quality of the audit (El-Siddiq, 2015). Our analysis show that joint audit improves the audit planning quality. In particular, we conclude that joint audit has a positive impact on the initial audit planning. We further document that joint audit has a positive impact on the comprehensive audit strategy. Finally, we find that joint audit has a positive impact on the overall audit plan and program. In addition, our analysis suggests on regulators to investigate the possibility of making joint audit voluntary for all companies and appointing the two parties of joint audit, one of them is from Big 4 offices and the other from non-big 4 offices.

The reminder of our paper is structured as follows; in section 2, we review extant related studies and develop our main hypothesis. In section 3 , we describe our sample. In section 4, we present descriptive statistics. In section 5, we present reliability analysis and correlation results. In section 6 , we discuss our main regression results. Finally, we conclude in section 7 .

\section{Literature review and research hypotheses}

The success of the audit engagement depends on the efficiency and effectiveness of its planning (Johnston \& Bedard, 2003; Sakr, 2018). 
Samra, Y.M.A. \& Elzahar, H. M.A. \& Fayed, H.M.A.

Proper audit planning allows the auditor to gather sufficient and appropriate auditing evidence in order to summarize appropriate opinion on the validity and fairness of the client's financial statements (Burke, 2015). Consequently, there is a close relationship between the proper audit planning and performing the audit at high level of quality. Thus, the results of proper planning will be reflected on audit quality, financial reporting quality, and the accuracy audit report. In addition, the failure of audit planning means the failure of the audit stages that follow, and consequently the failure of the audit process as a whole (Fan et al., 2015; Sakr, 2018).

Most of prior research on joint audit settings has devoted much attention towards investigating the impact of joint audit on the final stages of auditing, these studies found that joint audit could affect the audit quality, either directly or indirectly through its effect on financial reporting quality, earnings quality, detecting fraud and reporting it, and accuracy of audit report. The evidence from these studies was decidedly mixed. On the other hand, there is a lack of studies that have been addressed the topic of audit planning quality. The literature review can be classified in to two categories as follows:

\section{First: Studies related to joint audit}

Benali (2013); Abdel-Hamid (2014) suggested that joint audits can be considered as a corporate governance mechanism. Company whose management knows that its business is subject to audit by two independent auditors, it will be more compliant with the various policies, procedures, and regulations. Moreover, if the company's choice of the joint audit is voluntary, it provides an impression about the quality level of reporting, financial information and overall level of compliance. ElAssy (2015) concluded that companies audited by joint auditors are more conservative than companies audited by single auditor. Ittonen \& Tronnes (2015) also concluded that joint engagement partners could be positively associated with greater accruals quality. Bisogno \& De luca (2016) found that joint audit effects positively on both the accuracy of financial reporting in SMEs and earnings quality, which contributes in reducing earnings management. 
Scientific Journal for Financial and Commercial Studies and Researches (SJFCSR) Faculty of Commerce - Damietta University

The code of professional conduct required that the auditor should have a set of professional ethics, especially independence (AICPA, 2017). Piot (2007) demonstrated that a joint audit enhances auditor independence compared to a single audit because management's ability to influence two auditors together is less than its ability to influence only one auditor. This can add greater credibility to the client's financial statements, and increasing the users' confidence on these statements. In this context, Abdelmoula \& Affes (2019) found that the quality of the joint audit contributes to the prediction of three factors, namely competence, independence and reputation. Benali (2013) documented that when two Big4 auditors participate, it increases the shareholders' confidence, which is reflected positively on the stock prices of the enterprise. Another similar study carried out by Galy (2018) documented that most companies that apply joint audit have high accounting conservatism practices, which lead to increase the future firm value and create additional investment opportunities. On the contrary, Zerni et al. (2012) stated that the joint audit could negatively affect and threat the auditors' independence. Because, it may lead to the problem of "Free Riding", which means "one of the auditors exerted the greatest effort during the audit process, while the other auditor depends on what the first auditor did without exerting appropriate and sufficient effort to verify his work". In an investigative approach, Quick \& Schmidt (2018) found that there is a negative effect for joint audit on auditor independence and there is no effect for joint audit on audit quality. Unlike, Barghathi et al. (2020) concluded that joint audit might improve audit quality at the cost of high fees and free-rider problems.

Given that joint audit works on activating the mandatory discussion not voluntary among the audit team members in the planning and performing the audit, with respect to the possibility that the client's financial statements contain material misstatements resulting from fraud (El-Assy, 2015). It provides auditors a greater opportunity to select a more experienced and efficient staff than single audit through the high level of discussion among joint auditors, their various specialized expertise and the division of audit tasks among them (Velte, 2017). In the context of Quick \& Schmidt (2018) attempted to investigate the impact of joint audit and mandatory rotation of auditor-on-auditor independence 
Samra, Y.M.A. \& Elzahar, H. M.A. \& Fayed, H.M.A.

and audit quality. In their study, they argued that "four-eyes principle" can help to mitigate the negative effect of the mandatory rotation of auditor. This is through preserving the advantage of the client-good knowledge in assessing material errors in the financial statements and reducing the cost of client-specific knowledge, thereby providing continuity as one firm remains in place that is familiar with the business.

Similarity, Bianchi (2018) concluded that the cooperation of two joint auditors in practicing joint audit tasks could enhance knowledge transfer and increase the experience of joint auditors. Haak et al. (2018) in France documented that unbalanced allocation of joint audit work reduces free riding problem, which enhances audit quality. Bisogno \& De Luca (2016) indicated that the coordination, cooperation and frequent consultations between the two joint audit teams achieve a sufficient understanding of the core issues associated with audit risk and improve audit procedures. This is supported by Youssef (2015) concluded that the auditors' assessment of the fraud risks through the joint audit is more accurate and efficient than the auditors' assessment of these risks through the single audit because joint audit can improve auditors' ability to assess and report fraud in the financial statements.

As the expected penalties for the approval of reports inconsistent with accounting standards are likely to exceed its expected benefits, where the benefits and returns have been divided but the penalties will be borne by each (Zerni et al., 2012). Therefore, it is less likely for any of the auditors to agree to issue an audit report that is contrary to reality. The proof is that Baldauf \& Steckel (2012) found that there is a greater consensus between the joint auditors' opinions, and the audit report issued by the joint auditors is more accurate and more conservative compared to the report issued single auditors. They attributed the reason for this to the high level of communication and discussion between the joint auditors, the various specialization experiences, the division of audit tasks between them, and the exchange of brief reports on the audit work. This is consistent with the same conclusion by (Abdel-Qawi, 2017) who concluded that the joint audit leads to more conservative audit reports compared to the single audit. 
Scientific Journal for Financial and Commercial Studies and Researches

(SJFCSR) Faculty of Commerce - Damietta University

\section{Second: Studies related to audit planning quality}

Hassoubh (2017) tested the impact of the client's misleading practices for auditors (e.g., diversionary statements, distracting errors, or the two methods together) on the auditor's performance quality for analytical examination, as one of the most important audit planning procedures. He also examined the impact of the auditor's professional skepticism and his professional experience on audit-planning quality. The findings showed that there is a negative effect of the client's misleading practices for the auditor by following the diversionary statements method, distracting errors, and the two methods together on auditplanning quality. Specifically, the results indicated that the following of the two methods of misleading together is the most negative effect on the auditors' ability to detect and identify the material misstatements, followed by the negative effect of the distraction errors and then diversionary statements. He also concluded that there is a positive relationship between the auditor's professional skepticism and the auditplanning quality when the client follows the different methods of misleading practices. While, there is no significant relationship between the auditor's professional experience and the audit-planning quality when the auditor is misled by the different methods. Moreover, Sakr (2018) aimed at measuring the relationship between audit quality and the requirements of the strategic audit planning, and to identify the possibilities of practical application of this method in the Egyptian environment. This is throughout the development of the traditional planning concept of the audit to become a strategic planning. The findings showed that there is a significant positive relationship between the audit quality and the requirements of strategic audit planning (internal control assessment, business risk assessment, fraud assessment, and the extent of the use of information technology). There is also a positive statistical relationship between the audit risks and the strategic audit planning requirements. There is a positive statistical relation between strategic audit planning requirements and the improvement in audit planning. In addition, He found that the effect of strategic planning requirements combined, leads to a higher audit quality more than the effect of each requirement separately, and leads to a lower audit risk more than the effect of each requirement separately. 
Samra, Y.M.A. \& Elzahar, H. M.A. \& Fayed, H.M.A.

Based on prior research (Fernando et al., 2010; Hassoubh, 2017; Abdel-Halim, 2019; Ali, 2019; Mahmoud, 2020), we include some variables that can affect the audit planning quality, which called the controlling variables namely, client's size, governance and institutional ownership. The estimated regression model includes these variables (controlling variables) within the measurement of the relationship between the independent variable and the dependent variable, but they do not fall within the scope of the current study. Fernando et al. (2010); Hassoubh (2017) points out large-sized companies have large number of deals and operations, which require more effective and efficient control over their internal operations, as well as a great effort in external auditing. This is due to the more the client's size, the more the tests and risks. In this context, Mahmoud (2020) who finds that when auditing large-sized companies, it must take into account the audit firm's specialization in the client's industry, and the audit office should be from the Big 4 firms. Ali (2019) indicates that the success of audit planning with high quality depends on the effectiveness of corporate governance mechanisms, as the governance mechanisms play a major role in the appropriate selection of auditors and provision of monitoring the company's internal performance, which reduce the risk degree associated with auditing the financial statements. They also create the appropriate environment for the auditors by ensuring good coordination between them and the various parties involved in the audit and reducing the obstacles that may face them or threaten their independence while performing the audit task (Abdel-Halim, 2019). Hassoubh (2017) shows that companies with increased institutional ownership have more agency conflicts as conflicts between owners and managers and conflicts between owners and creditors. Thus, owners will be keener to ensure the possible highest level of audit planning quality and audit quality as a whole, in an attempt to reassure owners and creditors that the financial statements actually reflect the proper financial position of the company.

That is, based on these empirical studies, joint audit would play an import role in increasing audit quality, either directly or indirectly. Where, the advantages of joint audit on audit quality exceeds its disadvantaged. Therefore, we expect that these advantages are due to the positive effect of the joint audit on the audit planning procedures. In 
Scientific Journal for Financial and Commercial Studies and Researches

(SJFCSR) Faculty of Commerce - Damietta University

particular, we use three proxies for audit planning quality; namely initial audit planning, developing a comprehensive audit strategy, and developing an overall audit plan and program.

H1: Joint audit has no impact on the initial planning of the audit.

H2: Joint audit has no impact on the development of a comprehensive audit strategy.

H3: Joint audit has no impact on the development overall audit plan and program.

\section{Data and sample}

Our sample is comprised with 400 professional auditors from different-sized auditing firms and academics from different Egyptian universities. Data were collected from October 2020 to March 2021. Of the questionnaires distributed, 283 were returned with a response rate of $70.75 \%$. However, 9 surveys were dropped from the research because of incomplete and inconsistent data. Therefore, our final sample includes 274 questionnaires.

Panel A of Table 1 shows the categories of the research sample. The majority of respondents that are involved in the research are academics from different Egyptian universities representing 51.09\%, followed by professionals with $48.91 \%$. Panel B of Table 1 shows the position title of the research sample where $19.34 \%$ of respondents are senior auditors, $11.31 \%$ are juniors, $8.76 \%$ are audit firm owners, $5.47 \%$ are audit managers, and $4.02 \%$ are audit partners. Panel $\mathrm{C}$ of Table 1 shows that the majority of respondents are greater than 10 years representing $35.5 \%, 35.04 \%$ are lower than 5 years and $28.46 \%$ are between 5 years to 10 years.

Academics include staff working in auditing and accounting field namely, professors, lecturers, and assisstants. They also include students who are doing their master's degree in auditing and accounting.

Professionals include auditors working in different-sized auditing firms and with different years of experience. Junior auditors are performing most of the detailed audit work and their experience ranges from 0 to 2 years. Senior auditors are responsible for the audit field work, 
Samra, Y.M.A. \& Elzahar, H. M.A. \& Fayed, H.M.A.

including supervising and reviewing juniors' work, and their experience ranges from 2 to 5 years. Audit managers help the in-charge plan and manage the audit, review the in-charge's work, and their experience ranges from 5 to 10 years. Audit partners are the owners of audit firms and their experience is more than 10 years. They are responsible for reviewing the overall audit work and have the ultimate responsibility for conducting the audit and serving the client.

\section{Table (1) Sample Characteristics}

\begin{tabular}{|c|c|c|c|}
\hline Sample characteristic & Classification & Frequencies & percentage \\
\hline \multirow{3}{*}{$\begin{array}{c}\text { Panel (A) } \\
\text { Categories of study }\end{array}$} & Professionals & 134 & $48.91 \%$ \\
\hline & Academics & 140 & $51.09 \%$ \\
\hline & Total & 274 & $100 \%$ \\
\hline \multirow{7}{*}{$\begin{array}{c}\text { Panel (B) } \\
\text { Position Title }\end{array}$} & Junior auditor & 31 & $11.31 \%$ \\
\hline & Senior auditor & 53 & $19.34 \%$ \\
\hline & Audit Manager & 15 & $5.47 \%$ \\
\hline & $\begin{array}{l}\text { Audit partner (Large } \\
\text { firm) }\end{array}$ & 11 & $4.02 \%$ \\
\hline & $\begin{array}{l}\text { Audit partner (Small } \\
\text { firm) }\end{array}$ & 24 & $8.76 \%$ \\
\hline & Academics & 140 & $51.1 \%$ \\
\hline & Total & 274 & $100 \%$ \\
\hline \multirow{4}{*}{$\begin{array}{c}\text { Panel }(\mathbf{C}) \\
\text { Years of Experience }\end{array}$} & Lower than 5 years & 96 & $35.04 \%$ \\
\hline & $\begin{array}{c}\text { Between } 5 \text { years to } 10 \\
\text { years }\end{array}$ & 100 & $35.5 \%$ \\
\hline & Greater than 10 years & 78 & $28.46 \%$ \\
\hline & Total & 274 & $100 \%$ \\
\hline
\end{tabular}

\section{Descriptive statistics}

\subsection{Independent variable}

The main independent variable of interest in this study is joint audit (JA). Table 2 contains 25 sub-questions that aim to know the perceptions of respondents regarding the application of joint audit (JA) in the Egyptian Environment. Table 2 reports the descriptive statistics for (JA). The means of independent variable (JA) range from 2.49 to 4.54 . The standard deviations range from 0.54 to 0.76 and the coefficient of variations range from $11.89 \%$ to $29.18 \%$, which means that there is an agreement among the respondents and the variances are low because the 
Scientific Journal for Financial and Commercial Studies and Researches

(SJFCSR) Faculty of Commerce - Damietta University

standard deviation of any individual question is less than half of the related mean. Thus, low values of standard deviation and variation coefficients for all questions refer to low asymmetry in opinions for the sample. The average mean for the joint audit variable is 4.08 meaning that the majority of respondents are between agreeing and strongly agreeing to the joint audit approach.

The highest mean of 4.54 is on questions 1 where $57 \%$ of respondents strongly agree for applying joint audit approach and $41 \%$ of respondents who agree. There are no respondents who disagree or strongly disagree for this statement. Question 4 and question 6 have the second and the third highest mean of 4.53 and 4.51 respectively. These 2 questions relating to the difference in the size of the auditors and the type of joint audit regimes. Where, $48 \%$ of respondents in question 4 strongly agree with the statement that the two parties of joint audit, one of them should be from Big 4 offices and the other from non-big 4 offices, followed by $41 \%$ of respondents who agree and $11 \%$ who neutral. While, $56 \%$ of respondents in question 6 strongly agree with the statement that the application of joint audit should be voluntary for all companies, followed by $37 \%$ of respondents who agree and $7 \%$ who neutral. Question 5 has the lowest mean of 2.49. More than half, 55\% of respondents disagree with the statement that the application of joint audit should be mandatory for all companies, followed by $33 \%$ of respondents who neither agree nor disagree (neutral) and $9 \%$ of respondents who agree. A surprising finding is on question 7, which is the opposite of question 5, which has the fourth lowest mean of 2.74 where $44 \%$ of respondents disagree with the statement that the application of joint audit should be mandatory for some companies and voluntary for others according to the nature and characteristics of each company while $38 \%$ neutral. Questions 2 and 3 asking to what extend the respondents agree that both parties of joint audit should be from the non-big 4 offices and both parties of joint audit should be from the Big 4 offices respectively have the second and third lowest mean of 2.57 and 2.59 respectively. The responses for these two questions are in the same line where $52 \%$ of respondents disagree with the two statements while $32 \%$ of respondents neither agree nor disagree (neutral) for question 2 and $35 \%$ for question 3 . 
Samra, Y.M.A. \& Elzahar, H. M.A. \& Fayed, H.M.A.

We see that the voluntary joint audit gives freedom to companies to choose between single or joint audit according to the nature, characteristics of each company and the size of its business. This is consistent with Lessage et al. (2012); Ittonen \& Peni (2012) who showed that voluntarily appointing two auditors is associated with lower audit fees and signals a higher level of audit quality to the market. The European Commission (2011b) also supports the last views where it indicated that making joint audit mandatory couldn't be justified due to additional complexity and workload, expected increases in cost, and severe criticism from countries with previous experience in mandating this approach. For instance, Denmark abandoned the mandatory joint audit in 2005, because it did not result in any tangible benefits from an audit quality perspective (Bedard et al., 2014). Although joint audit is abandoned in Denmark, it is still used voluntarily by the 16 of Denmark's 64 largest public companies.

In addition, the appointing one of the joint audit parties from Big 4 firms, helps companies to send good signals to the investors that they have distinct audits and the signature of a big 4 auditor on the audit report gives investors impression about the high level of trust, reliability, and governance for audits. While, appointing the other one from non-Big 4 firms helps to mitigate the audit market concentration. This is consistent with Paugam \& Casta (2012); Abdel-Hamid (2014); Mahmoud (2017) showed that the choice of a Big 4 auditor with another non-Big 4 auditor is aimed at benefiting from the high reputation of Big 4 auditor, and benefiting from the services of non-Big 4 auditor, but at a lower cost. Marnet et al. (2018) also indicated that when a Big 4 auditor is paired with another non-Big 4 auditor, it assists small and mid-tier firms to acquire major clients, providing them with the experience, and allowing them to invest as needed to grow their presence in the large company market, which can reduce the audit market concentration. This is consistent with Paugam \& Casta (2012); Abdel-Hamid (2014); Mahmoud (2017); Marnet et al. (2018) while, it is contrast with the views of Francis et al. (2009); Audousset-Coulier (2014); Alfarih (2016) who argued that the appointing of two big 4 firms is the best choice when performing joint audit tasks. 
Scientific Journal for Financial and Commercial Studies and Researches

(SJFCSR) Faculty of Commerce - Damietta University

\subsection{Dependent variables}

The dependent variable, audit planning quality (APQ) is divided in to three variables namely, the initial audit planning, the comprehensive audit strategy, and the overall audit plan and program.

Table 3 contains 25 sub-questions for measuring the initial audit planning (IAP). Table 3 reports the descriptive statistics for (IAP). The means range from 3.94 to 4.55 . The standard deviations range from 0.54 to 0.78 and the coefficient of variations range from $11.87 \%$ to $18.92 \%$, which means that there is an agreement among the respondents and the variances are low because the standard deviation of any individual question is less than half of the related mean. Thus, low values of standard deviation and variation coefficients for all questions refer to low asymmetry in opinions for the sample. The average mean for (IAP) variable is 4.30 meaning that the majority of respondents think the questions asked are between influential and very influential to the initial audit-planning variable. The highest mean of 4.55 is on question 4 where $57 \%$ of respondents think that the assessment of the client's management integrity is very influential to the initial audit planning, followed by $41 \%$ who think it is influential. Question 20 has the lowest mean of 3.94. 23\% of respondents think the communication of the successor auditor with the predecessor auditor in order to understand the nature of dealing with the client is somewhat influential to the initial audit planning while $22 \%$ and $53 \%$ of respondents think it is very influential and influential respectively.

Table 4 contains 24 sub-questions for measuring the comprehensive audit strategy (CAS). Table 4 reports the descriptive statistics for (CAS). The means range from 4.18 to 4.52 . The standard deviations range from 0.27 to 0.72 and the coefficient of variations range from $6.26 \%$ to $17.18 \%$, which means that there is an agreement among the respondents and the variances are low because the standard deviation of any individual question is less than half of the related mean. Thus, low values of standard deviation and variation coefficients for all questions refer to low asymmetry in opinions for the sample. The average mean for the comprehensive audit strategy variable is 4.37 meaning that the majority of respondents think the questions asked are between influential and very influential to the comprehensive audit strategy variable. The highest mean of 4.52 is on question 11 where $54 \%$ of respondents think 
Samra, Y.M.A. \& Elzahar, H. M.A. \& Fayed, H.M.A.

that the assessment of the client's ability to continue in his activity is very influential to the comprehensive audit strategy, followed by $43 \%$ who think it is influential. Question 6 has the lowest mean of $4.18 .31 \%$ of respondents think that the need for external experts in complex tasks is very influential, followed by $58 \%$ who think it is influential and $10 \%$ somewhat influential.

Table 5 contains 8 sub-questions for measuring the overall audit plan and program (OAPP). Table 5 reports the descriptive statistics for (OAPP). The means range from 4.31 to 4.52 . The standard deviations range from 0.56 to 0.62 and the coefficient of variations range from $12.50 \%$ to $14.06 \%$, which means that there is an agreement among the respondents and the variances are low because the standard deviation of any individual question is less than half of the related mean. Thus, low values of standard deviation and variation coefficients for all questions refer to low asymmetry in opinions for the sample. The average mean for the overall audit plan and program variable is 4.42 meaning that the majority of respondents think the questions asked are between influential and very influential to the overall audit plan and program variable. The highest mean of 4.52 is on question 6 where $55 \%$ of respondents think that developing an accurate program that helps achieve the audit objectives is very influential to the overall audit plan and program, followed by $41 \%$ who think it is influential and $4 \%$ thinking it is somewhat influential. Questions 1 and 4 have the second and the third highest mean, which is 4.48 and 4.44 respectively. Where about $50 \%$ of respondents think that determining the audit tasks and efficient distribution of them and determining the extent, nature and timing of the audit procedures are very influential and $46 \%$ who think they are influential.

From the ranking mentioned in tables $(3,4,5)$, they show that the elements in the last rank do not mean that they do not affect the dependent variables (IAP, CAS, OAPP), as this ranking does not cancel the effect of those elements. Where, all of these factors obtained a value above the average, as the arithmetic mean is increased of 2.5 for all the elements, which means that all these elements have a great influence on the dependent variables, but with the different degree of influence of each element. 
Scientific Journal for Financial and Commercial Studies and Researches (SJFCSR) Faculty of Commerce - Damietta University

Table 2 Descriptive statistics for joint audit (JA) (Independent variable)

\begin{tabular}{|c|c|c|c|c|c|}
\hline & Question & Mean & $\begin{array}{c}\text { Std. } \\
\text { Deviation }\end{array}$ & $\begin{array}{c}\text { Cof. } \\
\text { Variation } \\
\end{array}$ & Rank \\
\hline Q 1 & Applying joint audit approach. & 4.54 & 0.54 & $11.89 \%$ & 1 \\
\hline Q 2 & $\begin{array}{l}\text { Both parties of joint audit } \\
\text { should be from the Big } 4 \text { offices }\end{array}$ & 2.57 & 0.75 & $29.18 \%$ & 24 \\
\hline Q 3 & $\begin{array}{l}\text { Both parties of joint audit } \\
\text { should be from the non-big } 4 \\
\text { offices. }\end{array}$ & 2.59 & 0.64 & $24.71 \%$ & 23 \\
\hline Q 4 & $\begin{array}{l}\text { The two parties of joint audit, } \\
\text { one of them should be from Big } \\
4 \text { offices and the other from } \\
\text { non-big } 4 \text { offices. }\end{array}$ & 4.53 & 0.56 & $12.33 \%$ & 2 \\
\hline Q 5 & $\begin{array}{l}\text { The application of joint audit } \\
\text { should be mandatory for all } \\
\text { companies. }\end{array}$ & 2.49 & 0.68 & $27.31 \%$ & 25 \\
\hline Q 6 & $\begin{array}{l}\text { The application of joint audit } \\
\text { should be voluntary for all } \\
\text { companies. }\end{array}$ & 4.51 & 0.59 & $13.11 \%$ & 3 \\
\hline Q 7 & $\begin{array}{l}\text { The application of joint audit } \\
\text { should be mandatory for some } \\
\text { companies and voluntary for } \\
\text { others according to the nature } \\
\text { and characteristics of each } \\
\text { company. }\end{array}$ & 2.74 & 0.75 & $27.37 \%$ & 22 \\
\hline Q 8 & $\begin{array}{l}\text { Joint audit can enhance the } \\
\text { auditors' confidence regarding } \\
\text { their decision whether } \\
\text { accepting new client or } \\
\text { continuing with the current. }\end{array}$ & 4.49 & 0.61 & $13.59 \%$ & 4 \\
\hline Q 9 & $\begin{array}{l}\text { The existence of two audit firms } \\
\text { can consider a strong indicator } \\
\text { of greater protection of auditor } \\
\text { independence compared to } \\
\text { single audit. }\end{array}$ & 4.41 & 0.56 & $12.70 \%$ & 10 \\
\hline Q 10 & $\begin{array}{l}\text { Joint audit can weak the } \\
\text { financial and economic } \\
\text { connection between the auditor } \\
\text { and the client and thus it } \\
\text { reduces the risk of collusion } \\
\text { between them. }\end{array}$ & 4.02 & 0.76 & $18.91 \%$ & 21 \\
\hline
\end{tabular}


Samra, Y.M.A. \& Elzahar, H. M.A. \& Fayed, H.M.A.

\begin{tabular}{|c|c|c|c|c|c|}
\hline & Question & Mean & $\begin{array}{c}\text { Std. } \\
\text { Deviation }\end{array}$ & $\begin{array}{c}\text { Cof. } \\
\text { Variation }\end{array}$ & Rank \\
\hline Q 11 & $\begin{array}{l}\text { Joint responsibility of joint } \\
\text { auditors can lead to vigilance } \\
\text { by each party to resist any } \\
\text { interventions } \\
\text { independence. }\end{array}$ & 4.34 & 0.65 & $14.98 \%$ & 14 \\
\hline Q 12 & $\begin{array}{l}\text { Joint audit can provide an } \\
\text { important advantage namely, } \\
\text { the ability of each auditor to } \\
\text { verify the work of the other } \\
\text { auditor, thus it can overcome } \\
\text { the problem of free riding. }\end{array}$ & 4.11 & 0.75 & $18.25 \%$ & 20 \\
\hline Q 13 & $\begin{array}{l}\text { The existence of two audit firms } \\
\text { during setting the engagement's } \\
\text { terms can represent a strong } \\
\text { claim for auditors against the } \\
\text { client if he violates any term of } \\
\text { the engagement. }\end{array}$ & 4.41 & 0.62 & $14.06 \%$ & 11 \\
\hline Q 14 & $\begin{array}{l}\text { The existence of two audit firms } \\
\text { during setting the engagement's } \\
\text { terms can represent a strong } \\
\text { claim against the auditors, if } \\
\text { one of them violated the terms, } \\
\text { which can reduce the legal } \\
\text { liability. }\end{array}$ & 4.42 & 0.6 & $13.57 \%$ & 9 \\
\hline Q 15 & $\begin{array}{l}\text { Joint audit can be considered as } \\
\text { one of the possible solutions to } \\
\text { mitigate the negative effects of } \\
\text { the mandatory rotation of } \\
\text { auditor. }\end{array}$ & 4.23 & 0.61 & $14.42 \%$ & 18 \\
\hline Q 16 & $\begin{array}{l}\text { Joint audit can preserve the } \\
\text { advantage of the client-good } \\
\text { knowledge during the } \\
\text { mandatory rotation of auditor. }\end{array}$ & 4.31 & 0.61 & $14.15 \%$ & 15 \\
\hline Q 17 & $\begin{array}{l}\text { Joint audit can reduce the cost } \\
\text { of client-specific knowledge } \\
\text { during the mandatory rotation } \\
\text { of auditor. }\end{array}$ & 4.24 & 0.68 & $16.04 \%$ & 17 \\
\hline Q 18 & $\begin{array}{l}\text { Joint audit can provide a large } \\
\text { amount of expertise and } \\
\text { possibilities available to each } \\
\text { auditor when developing the } \\
\text { comprehensive audit strategy. }\end{array}$ & 4.48 & 0.61 & $13.62 \%$ & 5 \\
\hline
\end{tabular}


Scientific Journal for Financial and Commercial Studies and Researches

(SJFCSR) Faculty of Commerce - Damietta University

\begin{tabular}{|c|c|c|c|c|c|}
\hline \multicolumn{6}{|c|}{ Table 2 (Continued) } \\
\hline Q 19 & $\begin{array}{l}\text { Joint audit can enhance the ability of } \\
\text { auditors to adequately understand the } \\
\text { nature of events and transactions of the } \\
\text { client. }\end{array}$ & 4.29 & 0.62 & $14.45 \%$ & 16 \\
\hline Q 20 & $\begin{array}{l}\text { Joint audit can make auditors more } \\
\text { committed with benchmarks needed } \\
\text { for evaluating materiality. }\end{array}$ & 4.43 & 0.62 & $14.00 \%$ & 8 \\
\hline Q 21 & $\begin{array}{l}\text { Joint audit can reduce the possibilities } \\
\text { of audit risk because misstatements } \\
\text { can be detected by the other joint } \\
\text { auditor. }\end{array}$ & 4.21 & 0.61 & $14.49 \%$ & 19 \\
\hline Q 22 & $\begin{array}{l}\text { Joint audit can make the client's } \\
\text { management more committed to } \\
\text { controls that affect the efficiency and } \\
\text { effectiveness of company operations } \\
\text { related to the internal control system. }\end{array}$ & 4.48 & 0.64 & $14.29 \%$ & 6 \\
\hline Q 23 & $\begin{array}{l}\text { The auditors' assessment of the fraud } \\
\text { risks through the joint audit is more } \\
\text { accurate than the auditors' assessment } \\
\text { of these risks through the single audit. }\end{array}$ & 4.46 & 0.61 & $13.68 \%$ & 7 \\
\hline Q 24 & $\begin{array}{l}\text { Joint audit can enhance the } \\
\text { professional skepticism levels of } \\
\text { auditors in order to accurately } \\
\text { evaluate any potential fraudulent } \\
\text { misstatements. }\end{array}$ & 4.38 & 0.64 & $14.61 \%$ & 12 \\
\hline Q 25 & $\begin{array}{l}\text { Joint audit can increase the level of } \\
\text { coordination and cooperation among } \\
\text { auditors, which enables them to } \\
\text { develop an integrated audit plan and } \\
\text { program. }\end{array}$ & 4.35 & 0.73 & $16.78 \%$ & 13 \\
\hline & Average & 4.0812 & 0.6416 & $16.50 \%$ & \\
\hline
\end{tabular}


Samra, Y.M.A. \& Elzahar, H. M.A. \& Fayed, H.M.A.

Table 3 Descriptive statistics for initial audit planning (IAP) (dependent variable)

\begin{tabular}{|l|l|c|c|c|c|}
\hline & \multicolumn{1}{|c|}{ Question } & Mean & $\begin{array}{c}\text { Std. } \\
\text { Deviation }\end{array}$ & $\begin{array}{c}\text { Cof. } \\
\text { Variation }\end{array}$ & Rank \\
\hline Q 1 & $\begin{array}{l}\text { The acceptance of the clients } \\
\text { who are more compliant with } \\
\text { the various policies and } \\
\text { procedures. }\end{array}$ & 4.54 & 0.62 & $13.66 \%$ & 2 \\
\hline Q 2 & $\begin{array}{l}\text { The reduction of the client's } \\
\text { pressures on the auditor to } \\
\text { influence on his decisions. }\end{array}$ & 4.07 & 0.77 & $18.92 \%$ & 22 \\
\hline Q 3 & $\begin{array}{l}\text { The assessment of auditors } \\
\text { ability to face the complexity of } \\
\text { decisions. }\end{array}$ & 4.40 & 0.55 & $12.50 \%$ & 8 \\
\hline Q 4 & $\begin{array}{l}\text { The assessment of the client's } \\
\text { management integrity. }\end{array}$ & 4.55 & 0.54 & $11.87 \%$ & 1 \\
\hline Q 5 & $\begin{array}{l}\text { The reduction of contracting } \\
\text { with high-risk clients. }\end{array}$ & 4.03 & 0.74 & $18.36 \%$ & 23 \\
\hline Q 6 & $\begin{array}{l}\text { The investigation of the client's } \\
\text { level of transparency in } \\
\text { disclosing any deterioration in } \\
\text { his assets for fear of exposure } \\
\text { to any risks. }\end{array}$ & 4.29 & 0.67 & $15.62 \%$ & 16 \\
\hline Q 7 & $\begin{array}{l}\text { The assessment of exposure to } \\
\text { the auditor's business risk. }\end{array}$ & 4.32 & 0.69 & $15.97 \%$ & 14 \\
\hline Q 8 & $\begin{array}{l}\text { The assessment of exposure to } \\
\text { the litigation risk. }\end{array}$ & 4.18 & 0.66 & $15.79 \%$ & 18 \\
\hline Q 9 & $\begin{array}{l}\text { The assessment of exposure to } \\
\text { the loss of reputation. }\end{array}$ & 4.32 & 0.67 & $15.51 \%$ & 13 \\
\hline Q 10 & $\begin{array}{l}\text { The assessment of auditors } \\
\text { compliance with ethical } \\
\text { requirements, especially } \\
\text { independence. }\end{array}$ & 4.44 & 0.65 & $14.64 \%$ & 7 \\
\hline Q 11 & $\begin{array}{l}\text { The provision of professional } \\
\text { competence and due diligence. }\end{array}$ & 4.52 & 0.61 & $13.50 \%$ & 4 \\
\hline Q 12 & $\begin{array}{l}\text { The auditors enjoying with the } \\
\text { independence of mind and } \\
\text { independence in appearance. }\end{array}$ & 4.27 & 0.68 & $15.93 \%$ & 17 \\
\hline
\end{tabular}


Scientific Journal for Financial and Commercial Studies and Researches

(SJFCSR) Faculty of Commerce - Damietta University

\begin{tabular}{|c|c|c|c|c|c|}
\hline \multicolumn{6}{|c|}{ Table 3 (Continued) } \\
\hline Q 13 & $\begin{array}{l}\text { Ensuring that the audit team has the } \\
\text { opportunity to express opposing } \\
\text { opinions about the client objectively } \\
\text { and without bias. }\end{array}$ & 4.32 & 0.66 & $15.28 \%$ & 12 \\
\hline Q 14 & $\begin{array}{l}\text { Obtaining information on the needs of } \\
\text { the client's request for the audit. }\end{array}$ & 4.49 & 0.61 & $13.59 \%$ & 5 \\
\hline Q 15 & $\begin{array}{l}\text { The assessment of the acceptable audit } \\
\text { risk accurately. }\end{array}$ & 4.30 & 0.57 & $13.26 \%$ & 15 \\
\hline Q 16 & $\begin{array}{l}\text { Understanding the client's requests } \\
\text { better in order to document the } \\
\text { engagement terms without errors and } \\
\text { reduce misunderstanding. }\end{array}$ & 4.32 & 0.59 & $13.66 \%$ & 11 \\
\hline Q 17 & $\begin{array}{l}\text { Determining the responsibilities of the } \\
\text { auditor and management. }\end{array}$ & 4.47 & 0.64 & $14.32 \%$ & 6 \\
\hline Q 18 & $\begin{array}{l}\text { Both parties (the client and the auditor) } \\
\text { are committed to the terms of the } \\
\text { contract. }\end{array}$ & 4.39 & 0.62 & $14.12 \%$ & 9 \\
\hline Q 19 & $\begin{array}{l}\text { The communication of the successor } \\
\text { auditor with the predecessor auditor in } \\
\text { order to demonstrate his } \\
\text { professionalism. }\end{array}$ & 3.98 & 0.78 & $19.60 \%$ & 24 \\
\hline Q 20 & $\begin{array}{l}\text { The communication with the } \\
\text { predecessor auditor to understand the } \\
\text { nature of dealing with client. }\end{array}$ & 3.94 & 0.74 & $18.78 \%$ & 25 \\
\hline Q 21 & $\begin{array}{l}\text { The commitment of the successor } \\
\text { auditor to the confidentiality of the } \\
\text { information obtained. }\end{array}$ & 4.12 & 0.75 & $18.20 \%$ & 21 \\
\hline Q 22 & $\begin{array}{l}\text { The verification of the quality of the } \\
\text { information obtained from the } \\
\text { predecessor auditor. }\end{array}$ & 4.17 & 0.73 & $17.51 \%$ & 19 \\
\hline Q 23 & $\begin{array}{l}\text { The awareness of successor auditor of } \\
\text { certain technical and ethical facts or } \\
\text { circumstances that were disclosed by } \\
\text { the predecessor auditor. }\end{array}$ & 4.17 & 0.74 & $17.75 \%$ & 20 \\
\hline Q 24 & $\begin{array}{l}\text { The selection of an experienced and } \\
\text { efficient audit team. }\end{array}$ & 4.54 & 0.63 & $13.88 \%$ & 3 \\
\hline Q 25 & $\begin{array}{l}\text { Industry specialization of the audit } \\
\text { team auditing the client company. }\end{array}$ & 4.37 & 0.59 & $13.50 \%$ & 10 \\
\hline & erage & 4.304 & 0.66 & $15.35 \%$ & \\
\hline
\end{tabular}


Samra, Y.M.A. \& Elzahar, H. M.A. \& Fayed, H.M.A.

Table 4 Descriptive statistics for comprehensive audit strategy (CAS) (dependent variable)

\begin{tabular}{|c|c|c|c|c|c|}
\hline & Question & Mean & $\begin{array}{c}\text { Std. } \\
\text { Deviation }\end{array}$ & $\begin{array}{c}\text { Cof. } \\
\text { Variation }\end{array}$ & Rank \\
\hline Q 1 & $\begin{array}{l}\text { Adequate understanding of the } \\
\text { nature of the client's business } \\
\text { and industry. }\end{array}$ & 4.51 & 0.58 & $12.86 \%$ & 2 \\
\hline Q 2 & $\begin{array}{llr}\begin{array}{l}\text { Determining } \\
\text { objectives. }\end{array} & \text { the } & \text { audit } \\
\end{array}$ & 4.51 & 0.59 & 13.08 & 3 \\
\hline Q 3 & $\begin{array}{l}\text { Availability of a large amount } \\
\text { of expertise and possibilities } \\
\text { available to the audit team. }\end{array}$ & 4.50 & 0.59 & $13.11 \%$ & 4 \\
\hline Q 4 & $\begin{array}{l}\text { Determining the necessary } \\
\text { resources either physical or } \\
\text { human accurately. }\end{array}$ & 4.19 & 0.72 & $17.18 \%$ & 23 \\
\hline Q 5 & $\begin{array}{l}\text { Awareness of the audit team } \\
\text { with the advanced techniques } \\
\text { on auditing. }\end{array}$ & 4.39 & 0.71 & $16.17 \%$ & 12 \\
\hline Q 6 & $\begin{array}{l}\text { The need for external experts } \\
\text { in complex tasks. }\end{array}$ & 4.18 & 0.65 & $15.55 \%$ & 24 \\
\hline Q 7 & $\begin{array}{l}\text { Determining the quality of } \\
\text { appropriate } \\
\text { preliminary } \\
\text { analytical procedures. }\end{array}$ & 4.33 & 0.59 & $13.63 \%$ & 16 \\
\hline Q 8 & $\begin{array}{l}\text { Availability of professional } \\
\text { expertise and personal } \\
\text { judgment for the audit team to } \\
\text { search for unusual events and } \\
\text { misstatements. }\end{array}$ & 4.24 & 0.56 & $13.21 \%$ & 22 \\
\hline Q 9 & $\begin{array}{l}\text { Understanding the nature of } \\
\text { the client's events and } \\
\text { transactions that have } \\
\text { occurred since the last audit } \\
\text { date. }\end{array}$ & 4.29 & 0.62 & $14.45 \%$ & 20 \\
\hline
\end{tabular}


Scientific Journal for Financial and Commercial Studies and Researches

(SJFCSR) Faculty of Commerce - Damietta University

\begin{tabular}{|c|c|c|c|c|c|}
\hline \multicolumn{6}{|c|}{ Table 4 (Continued) } \\
\hline Q 10 & $\begin{array}{l}\text { Distinguishing between the material and } \\
\text { immaterial differences in order to } \\
\text { determine the size of detailed tests. }\end{array}$ & 4.27 & 0.63 & $14.75 \%$ & 21 \\
\hline Q 11 & $\begin{array}{l}\text { The assessment of the client's ability to } \\
\text { continue in his activity. }\end{array}$ & 4.52 & 0.55 & $12.17 \%$ & 1 \\
\hline Q 12 & $\begin{array}{l}\text { Determining the acceptability of the } \\
\text { client's assertions about unusual } \\
\text { fluctuations. }\end{array}$ & 4.33 & 0.64 & $14.78 \%$ & 17 \\
\hline Q 13 & $\begin{array}{l}\text { Determining decisions related to } \\
\text { materiality. }\end{array}$ & 4.41 & 0.64 & $14.51 \%$ & 8 \\
\hline Q 14 & $\begin{array}{l}\text { The assessment of the planned detection } \\
\text { risk and inherent risk. }\end{array}$ & 4.31 & 0.27 & $6.26 \%$ & 18 \\
\hline Q 15 & $\begin{array}{l}\text { Adequate understanding of the core } \\
\text { issues associated with audit risk. }\end{array}$ & 4.30 & 0.67 & $15.58 \%$ & 19 \\
\hline Q 16 & Identifying and assessing control risks. & 4.43 & 0.58 & $13.09 \%$ & 7 \\
\hline Q 17 & $\begin{array}{l}\text { Adequate understanding of the client's } \\
\text { internal control system and } \\
\text { organizational structure. }\end{array}$ & 4.46 & 0.53 & $11.88 \%$ & 5 \\
\hline Q 18 & $\begin{array}{l}\text { Verifying the extent to which the client's } \\
\text { company has achieved its objectives. }\end{array}$ & 4.39 & 0.70 & $15.95 \%$ & 11 \\
\hline Q 19 & $\begin{array}{l}\text { Identifying the weaknesses and gaps in } \\
\text { the internal control system. }\end{array}$ & 4.45 & 0.60 & $13.48 \%$ & 6 \\
\hline Q 20 & $\begin{array}{l}\text { Verifying the client's compliance with } \\
\text { various rules, laws and regulations } \\
\text { related to internal control system. }\end{array}$ & 4.4 & 0.60 & $13.64 \%$ & 9 \\
\hline Q 21 & $\begin{array}{l}\text { Recognizing the conditions that will } \\
\text { increase the risk of fraudulent financial } \\
\text { reporting. }\end{array}$ & 4.39 & 0.58 & $13.21 \%$ & 10 \\
\hline Q 22 & $\begin{array}{l}\text { Thinking about the unexpected client- } \\
\text { side misstatements. }\end{array}$ & 4.35 & 0.53 & $12.18 \%$ & 14 \\
\hline Q 23 & $\begin{array}{l}\text { Innovating audit procedures to assess } \\
\text { potential fraud in the financial } \\
\text { statements. }\end{array}$ & 4.35 & 0.63 & $14.48 \%$ & 15 \\
\hline Q 24 & $\begin{array}{l}\text { Availability of professional knowledge } \\
\text { for audit team about the relevant audit } \\
\text { evidence that would address fraud risks } \\
\text { effectively. }\end{array}$ & 4.37 & 0.59 & $13.50 \%$ & 13 \\
\hline & Average & 4.369 & 0.597 & $13.68 \%$ & \\
\hline
\end{tabular}


Samra, Y.M.A. \& Elzahar, H. M.A. \& Fayed, H.M.A.

Table 5 Descriptive statistics for overall audit plan and program (OAPP) (dependent variable)

\begin{tabular}{|c|c|c|c|c|c|}
\hline & Question & Mean & $\begin{array}{c}\text { Std. } \\
\text { Deviation }\end{array}$ & $\begin{array}{c}\text { Cof. } \\
\text { Variation }\end{array}$ & Rank \\
\hline Q 1 & $\begin{array}{l}\text { Determining the audit tasks and } \\
\text { efficient distribution of them. }\end{array}$ & 4.48 & 0.56 & $12.50 \%$ & 2 \\
\hline Q 2 & $\begin{array}{l}\text { Determining the quality of } \\
\text { required evidence. }\end{array}$ & 4.38 & 0.56 & $12.79 \%$ & 7 \\
\hline Q 3 & $\begin{array}{l}\text { Determining the quantity of } \\
\text { sufficient evidence. }\end{array}$ & 4.41 & 0.62 & $14.06 \%$ & 6 \\
\hline Q 4 & $\begin{array}{l}\text { Determining the extent, nature } \\
\text { and timing of the audit } \\
\text { procedures. }\end{array}$ & 4.44 & 0.62 & $13.96 \%$ & 3 \\
\hline Q 5 & $\begin{array}{l}\text { Developing a good design of } \\
\text { audit program based on the } \\
\text { perceptions that auditors } \\
\text { develop during risk assessment } \\
\text { procedures. }\end{array}$ & 4.41 & 0.58 & $13.15 \%$ & 5 \\
\hline Q 6 & $\begin{array}{l}\text { Developing an accurate } \\
\text { program that helps achieve the } \\
\text { audit objectives. }\end{array}$ & 4.52 & 0.58 & $12.83 \%$ & 1 \\
\hline Q 7 & $\begin{array}{l}\text { Setting the appropriate audit } \\
\text { procedures in accordance with } \\
\text { Generally Accepted Auditing } \\
\text { standards (GAAS). }\end{array}$ & 4.41 & 0.57 & $12.93 \%$ & 4 \\
\hline \multirow[t]{2}{*}{ Q 8} & $\begin{array}{l}\text { Allocation of responsibilities } \\
\text { and tasks for auditors effectively } \\
\text { to avoid time-budget pressures. }\end{array}$ & 4.31 & 0.59 & $13.69 \%$ & 8 \\
\hline & Average & 4.42 & 0.585 & $13.24 \%$ & \\
\hline
\end{tabular}

\subsection{Control variables (See Appendix)}

Based on prior research on audit planning quality (Fernando et al., 2010; Hassoubh, 2017; Abdel-Halim, 2019; Ali, 2019; Mahmoud, 2020), we include some variables that can affect the audit planning quality, which called the controlling variables namely, client's size (S), governance $(\mathrm{G})$ and institutional ownership $(\mathrm{O})$. The estimated regression model includes these variables (controlling variables) within the 
Scientific Journal for Financial and Commercial Studies and Researches

(SJFCSR) Faculty of Commerce - Damietta University

measurement of the relationship between the independent variable and the dependent variable. This section contains 25 sub-questions that present the controlling variables.

Panel A reports the descriptive statistics for the control variable (S). The means related to client's size range from 4.14 to 4.42 . The standard deviations range from 0.59 to 0.75 and the coefficient of variations range from $13.35 \%$ to $18.12 \%$, which means that there is an agreement among the respondents and the variances are low because the standard deviation of any individual question is less than half of the related mean. Thus, low values of standard deviation and variation coefficients for all questions refer to low asymmetry in opinions for the sample. The average mean for the client's size variable is 4.31 meaning that the majority of respondents are between agreeing and strongly agreeing to factors related to large companies.

Panel B reports the descriptive statistics for the control variable (G). The means related to corporate governance range from 4.11 to 4.50 . The standard deviations range from 0.53 to 0.74 and the coefficient of variations range from $12.13 \%$ to $18.00 \%$, which means that there is an agreement among the respondents and the variances are low because the standard deviation of any individual question is less than half of the related mean. Thus, low values of standard deviation and variation coefficients for all questions refer to low asymmetry in opinions for the sample. The average mean for the corporate governance variable is 4.35 meaning that the majority of respondents are between agreeing and strongly agreeing to factors related to the effective corporate governance.

Panel C reports the descriptive statistics for the control variable (O). The means related to institutional ownership range from 4.29 to 4.37. The standard deviations range from 0.64 to 0.72 and the coefficient of variations range from $14.92 \%$ to $16.78 \%$, which means that there is an agreement among the respondents and the variances are low because the standard deviation of any individual question is less than half of the related mean. Thus, low values of standard deviation and variation coefficients for all questions refer to low asymmetry in opinions for the sample. The average mean for the institutional ownership variable is 4.32 meaning that the majority of respondents are between agreeing and 
Samra, Y.M.A. \& Elzahar, H. M.A. \& Fayed, H.M.A.

strongly agreeing to factors related to companies in which institutional ownership increase.

\section{Reliability analysis and correlation results}

5.1 Reliability Analysis

According to Mitchell \& Jolley (2012), alpha coefficient values larger than 0.60 are considered acceptable. Cronbach's alpha reliability coefficient is the square root of the Cronbach's Alfa and normally ranges between 0 and 1 . The greater Cronbach's alpha coefficient than 0.8 , the greater the stability and internal consistency of the items in the scale (Gliem \& Gliem 2003).

The Cronbach's alfa and reliability coefficient results are presented in Table 6. The values of Cronbach's alpha for all variables are greater than 0.6 and the Reliability Coefficients for all variables are greater than 0.8 , which mean higher stability and consistency for the questionnaire tool. Thus, these coefficients are reliable and can be useful in testing hypotheses and results generalization (Hair et al., 2010).

Table 6 Cronbach's Alfa and Reliability Coefficient results

\begin{tabular}{|c|c|c|c|}
\hline Main variables & $\begin{array}{c}\text { Number of } \\
\text { Items }\end{array}$ & $\begin{array}{c}\text { Cronbach's } \\
\text { Alfa }\end{array}$ & $\begin{array}{c}\text { Reliability } \\
\text { Coefficient }\end{array}$ \\
\hline Joint audit & 25 & 0.923 & 0.961 \\
\hline Initial audit planning & 25 & 0.947 & 0.973 \\
\hline Comprehensive audit strategy & 24 & 0.958 & 0.979 \\
\hline Overall audit plan and program & 8 & 0.927 & 0.963 \\
\hline All variables & $\mathbf{8 2}$ & $\mathbf{0 . 9 3 3}$ & $\mathbf{0 . 9 6 6}$ \\
\hline Control variables & Number of & Cronbach's & $\begin{array}{c}\text { Reliability } \\
\text { Coefficient }\end{array}$ \\
\hline Size & Items & Alfa & 0.952 \\
\hline Governance & 6 & 0.906 & 0.958 \\
\hline Institutional ownership & 13 & 0.918 & 0.961 \\
\hline All variables & 6 & 0.924 & $\mathbf{0 . 9 5 6}$ \\
\hline
\end{tabular}


Scientific Journal for Financial and Commercial Studies and Researches (SJFCSR) Faculty of Commerce - Damietta University

\subsection{Pearson Correlation Matrix}

The Pearson Correlation results are reported in Table 7. A strong positive correlation is found between independent variable Joint audit (X) and the two variables (Y1, Y2), the first and second components of the dependent variables: initial audit planning Y1, comprehensive audit strategy Y2, where the correlation coefficient is 0.879 and 0.826 respectively. We also find an intermediate positive correlation between the independent variable Joint audit (X) and the third component of the dependent variables: overall audit plan and program Y3, where the correlation coefficient is 0.669 . Moreover, there is a strong positive correlation between the second and third components of control variables: governance $\mathrm{C}$ 2, institutional ownership $\mathrm{C} 3$, and dependent variables (Y1, Y2, Y3) where the correlation coefficients for governance are $0.748,0.835 \& 0.723$ respectively, and for institutional ownership are $0.670,0.861 \& 0.728$ respectively. While, a strong negative correlation is found between the first component of control variables: size $\mathrm{C} 1$, and dependent variables (Y1, Y2) where the correlation coefficients are $0.777 \&-0.709$ respectively and a weak negative correlation relationship between the first component of control variables: size $\mathrm{C} 1$, and dependent variable (Y3) where the correlation coefficient is -475 .

Table 7 Pearson Correlation results

\begin{tabular}{|c|c|c|c|c|c|c|c|}
\hline Variables & $\begin{array}{c}\text { Joint } \\
\text { audit }\end{array}$ & $\begin{array}{c}\text { Initial } \\
\text { audit } \\
\text { planning }\end{array}$ & $\begin{array}{c}\text { Comprehensi } \\
\text { ve audit } \\
\text { strategy }\end{array}$ & $\begin{array}{c}\text { Overall } \\
\text { audit } \\
\text { plan and } \\
\text { program }\end{array}$ & Size & Governance & $\begin{array}{c}\text { Institutio } \\
\text { nal } \\
\text { ownership }\end{array}$ \\
\hline Joint audit (X) & 1 & & & & & & \\
\hline $\begin{array}{c}\text { Initial audit } \\
\text { planning (Y1) }\end{array}$ & $0.879^{* *}$ & 1 & & & & & \\
\hline $\begin{array}{c}\text { Comprehensive } \\
\text { audit strategy } \\
\text { (Y2) }\end{array}$ & $0.826^{* *}$ & $0.807^{* *}$ & 1 & & & & \\
\hline $\begin{array}{c}\text { Overall audit } \\
\text { plan and } \\
\text { program (Y3) }\end{array}$ & $0.669^{* *}$ & $0.568^{* *}$ & $0.748^{* *}$ & 1 & & & \\
\hline Size (C1) & $-0.740^{* *}$ & $-0.777^{* *}$ & $-0.709^{* *}$ & $-0.475^{* *}$ & 1 & & \\
\hline $\begin{array}{c}\text { Governance } \\
\text { (C2) }\end{array}$ & $\mathbf{0 . 8 0 4 * *}$ & $0.748^{* *}$ & $0.835^{* *}$ & $0.723^{* *}$ & $0.851^{* *}$ & 1 & 1 \\
\hline $\begin{array}{c}\text { Institutional } \\
\text { ownership (C3) }\end{array}$ & $0.752^{* *}$ & $0.670^{* *}$ & $0.861^{* *}$ & $0.728^{* *}$ & $0.731^{* *}$ & $0.803^{* *}$ & 1 \\
\hline
\end{tabular}


Samra, Y.M.A. \& Elzahar, H. M.A. \& Fayed, H.M.A.

\section{Hypotheses results}

\subsection{Multiple regression results}

The multiple regression results are reported in Table 8 . The model is statistically significant, where (t-static $>1.96$ and Sig. $<0.05$ ) (Moody, 2009) for the three hypotheses. Panel A reports the regression results for the first dependent variable (IAP). The coefficient on JA, our main variable of interest in Panel A, is positive and significant (Panel A) providing support for rejecting the first null hypothesis $(\mathrm{H} 1)$ and accepting the alternative hypothesis, which indicates there is a significant positive impact of joint audit on initial audit planning (coefficient 0.803 , $\mathrm{t}$ - statistic 16.122, Sig. $=0.000)$. This result in consistent with our theoretical prediction that joint audit enhances auditors' confidence regarding their decision whether accepting new client or continuing with the current by assessing the client's integrity, assessing the client's business risk effectively which helps them to select the proper client. This result is consistent with (Benali, 2013; Ittonen \& Tronnes, 2015; Bisogno \& De Luca, 2016; Lobo et al., 2017; Ibrahim, 2018) while this is contradicted to the results of Zerni et al. (2012).

Panel B reports the regression results for the second dependent variable (CAS). The coefficient on JA is positive and significant (Panel B) providing support for rejecting the second null hypothesis (H2) and accepting the alternative hypothesis, which indicates there is a significant positive impact of joint audit on comprehensive audit strategy (coefficient $0.497, \mathrm{t}-$ statistic 8.915 , Sig. $=0.000$ ). This result in consistent with our theoretical prediction that joint audit provides a large amount of expertise and possibilities available to each auditor when developing the comprehensive audit strategy, which helps in determining the audit objectives accurately. This is consistent with (Baldauf \& Steckel, 2012; Benali, 2013; Bianchi, 2018; Okaro et al., 2018).

Panel $\mathrm{C}$ reports the regression results for the third dependent variable (CAS). The coefficient on JA is positive and significant (Panel C) providing support for rejecting the third null hypothesis (H3) and accepting the alternative hypothesis, which indicates there is a significant positive impact of joint audit on overall audit plan and program (coefficient $0.432, \mathrm{t}$-statistic 5.001, Sig. $=0.000$ ). This result in consistent with our theoretical prediction that joint audit increases the level of coordination and cooperation among auditors, which enables 
Scientific Journal for Financial and Commercial Studies and Researches

(SJFCSR) Faculty of Commerce - Damietta University

them to develop an integrated audit plan and program. This is consistent with (Abdel-Hamid, 2014; Alsadoun \& Aljabr, 2014; Ittonen \& Trønnes, 2015; Ruwished, 2016).

According to the control variables in Panels $\mathrm{A}, \mathrm{B}$, and $\mathrm{C}$, the coefficients and $\mathrm{t}$ - statistics on $\mathrm{G}, \mathrm{O}$ are positive and significant, while the coefficient and $\mathrm{t}$-statistic on $\mathrm{S}$ is negative and significant. This indicates that there is a significant positive impact of control variables related to governance and institutional ownership while there is a significant negative impact of the control variable related to size. This is due to the effective corporate governance makes the boards of directors, audit committee, and internal auditors more committed to the rules and procedures and implementing their responsibilities effectively. This is consistent with (Abdel-Halim, 2019; Ali, 2019). The increasing of institutional ownership prevents the company's management from adopting opportunistic behaviors that conflict with the interests of other shareholders and increases managers' submission to supervision and control. This is consistent with (Hassoubh, 2017). While the increasing of the client's size means increasing the activities and the complexity of operations, which leads to increase tests and risks. This is consistent with (Fernando et al., 2010; Hassoubh, 2017; Mahmoud, 2020).

The explanatory coefficients $\left(\mathrm{R}^{2}\right)$ for the three dependent variables are $81.3 \%, 81.5 \%$ \& $64.4 \%$ respectively. Panel $A, \mathrm{R}^{2}(0.813)$ indicates that $81.3 \%$ of the change in initial audit planning is due to the independent variable "joint audit" and the control variables and the residual $18.7 \%$ is due to other factors. Panel $\mathrm{B}, \mathrm{R}^{2}(0.815)$ indicates that $81.5 \%$ of the change in comprehensive audit strategy is due to the independent variable "joint audit" and the control variables and the residual $18.5 \%$ is due to other factors. Panel C, $\mathrm{R}^{2}(0.644)$ indicates that $64.4 \%$ of the change in overall audit plan and program is due to the independent variable "joint audit" and the control variables and the residual $35.6 \%$ is due to other factors. Moreover, $\mathrm{F}$ values for the three dependent variables are $291.98,296.22 \& 121.85$ respectively at the level $(a=5 \%)$. This confirms the high explanatory strength of the model statistically. We can't find any problems related to the multicollinearity, because of the variance inflation factor (VIF) less than 10 for all independent and control variables (Hair et al., 2010). 
Samra, Y.M.A. \& Elzahar, H. M.A. \& Fayed, H.M.A.

\begin{tabular}{|c|c|c|c|c|c|c|c|c|c|c|c|c|}
\hline \multicolumn{13}{|c|}{$\begin{array}{l}\text { Based on the above results, we conclude that joint audit has a } \\
\text { significant positive impact on the audit planning quality. } \\
\text { Table } 8 \text { Multiple regression analysis results }\end{array}$} \\
\hline \multirow{2}{*}{$\begin{array}{c}\text { Variabl } \\
\text { es }\end{array}$} & \multicolumn{4}{|c|}{$\begin{array}{c}\text { Panel A: Dependent } \\
\text { Variable: Initial audit } \\
\text { planning }\end{array}$} & \multicolumn{4}{|c|}{$\begin{array}{c}\text { Panel B: Dependent } \\
\text { Variable: Comprehensive } \\
\text { audit strategy } \\
\end{array}$} & \multicolumn{4}{|c|}{$\begin{array}{l}\text { Panel C: Dependent } \\
\text { Variable: Overall audit } \\
\text { plan and program }\end{array}$} \\
\hline & $\begin{array}{c}\boldsymbol{\beta} \\
\text { Coef. } \\
\end{array}$ & $\begin{array}{c}\mathrm{t}- \\
\text { static }\end{array}$ & Sig & VIF & $\beta$ Coef. & t-static & Sig & VIF & B Coef. & t-static & Sig & VIF \\
\hline $\begin{array}{c}\text { Consta } \\
\text { nt }\end{array}$ & 0.206 & 1.67 & 0.096 & & 0.340 & 2.470 & 0.014 & & 0.900 & 4.214 & 0.000 & \\
\hline $\begin{array}{l}\text { Joint } \\
\text { Audit } \\
\end{array}$ & 0.803 & 16.122 & 0.000 & 2.979 & 0.497 & 8.915 & 0.000 & 2.979 & 0.432 & 5.001 & 0.000 & 2.979 \\
\hline Size & -0.278 & -6.637 & 0.000 & 3.872 & -0.130 & -2.291 & 0.006 & 3.872 & -0.537 & -7.500 & 0.000 & 3.872 \\
\hline $\begin{array}{c}\text { Govern } \\
\text { ance }\end{array}$ & 0.69 & 2.37 & 0.000 & 7.984 & 0.460 & 2.622 & 0.006 & 7.984 & 0.694 & 6.053 & 0.000 & 7.984 \\
\hline $\begin{array}{l}\text { Institut } \\
\text { ional } \\
\text { owners } \\
\text { hip } \\
\end{array}$ & 0.42 & 2.936 & 0.006 & 5.672 & 0.415 & 8.354 & 0.000 & 5.672 & 0.228 & 2.959 & 0.003 & 5.672 \\
\hline $\mathbf{N}$ & 274 & & & & 274 & & & & 274 & & & \\
\hline $\begin{array}{c}\text { F- } \\
\text { Value }\end{array}$ & 291.983 & & & & 296.215 & & & & 121.848 & & & \\
\hline $\mathbf{R}^{2}$ & $81.30 \%$ & & & & $81.50 \%$ & & & & $64.40 \%$ & & & \\
\hline
\end{tabular}

Confidence level is $95 \%$, sig. $<0.05$, $\mathrm{t}$ value \pm 1.96

Confidence level is $95 \%$, sig. $<0.05$, f value \pm 1.96

The $\mathbf{F}$ value and $\mathbf{T}$ value can be used to determine whether the test is statistically significant. An F value of at least \pm 1.96 is needed to reject the null hypothesis and accept the alternative hypotheses at an alpha level of 0.05 . $T$ value also should be at least \pm 1.96 to reject the null hypotheses (Moody, 2009).

\subsection{MANOVA Analysis results}

We use MANOVA analysis to identify the most dependent variables affected by the independent variables. MANOVA Analysis 
Scientific Journal for Financial and Commercial Studies and Researches (SJFCSR) Faculty of Commerce - Damietta University

results are reported in Table 9. The dependent variables can be arranged according to F value where Sig. $<0.05$ (Gujarati, 2003). According to the independent variable JA, IAP (Y1) is the most dependent variable affected by the independent variable JA (X) where $\mathrm{F}$ value is 46.596, followed by CAS (Y2), and then OAPP (Y3) where F values are 23.287 and 5.990 respectively. According to the control variable (S), CAS is the most dependent variable affected by the control variable "size" (C1) where $\mathrm{F}$ value is 78.973 , followed by IAP, and then OAPP where F values are 40.717 and 32.231 respectively. According to the control variable $(\mathrm{G}), \mathrm{CAS}$ is the most dependent variable affected by the control variable "governance" $(\mathrm{C} 2)$ where $\mathrm{F}$ value is 13.485 , followed by IAP, and then OAPP where $\mathrm{F}$ values are 11.521 and 11.381 respectively. According to the control variable (O), IAP is the most dependent variable affected by the control variable "ownership" (C3) where F value is 30.119 , followed by CAS, and then OAPP where F values are 20.328 and 4.389 respectively.

Table 9 MANOVA Analysis results

\begin{tabular}{|c|c|c|c|c|c|c|c|c|c|}
\hline Source & $\begin{array}{c}\text { Dependent } \\
\text { Variable }\end{array}$ & $\begin{array}{c}\text { Type III } \\
\text { Sum of } \\
\text { Squares } \\
\end{array}$ & df & \begin{tabular}{|c|} 
Mean \\
Square
\end{tabular} & $\mathbf{F}$ & Sig. & $\begin{array}{c}\text { Partial } \\
\text { Eta } \\
\text { Squared } \\
\end{array}$ & $\begin{array}{l}\text { Noncent. } \\
\text { Parameter }\end{array}$ & $\begin{array}{c}\text { Observed } \\
\text { Power }^{d}\end{array}$ \\
\hline \multirow{3}{*}{$\begin{array}{l}\text { Corrected } \\
\text { Model }\end{array}$} & $\mathrm{Y} 1$ & $36.128^{a}$ & 152 & .238 & 183.248 & .000 & .996 & 27853.652 & 1.000 \\
\hline & $\mathrm{Y} 2$ & $45.833^{\mathrm{b}}$ & 152 & .302 & 236.687 & .000 & .997 & 35976.449 & 1.000 \\
\hline & $\mathrm{Y} 3$ & $56.805^{\mathrm{c}}$ & 152 & .374 & 59.980 & .000 & .987 & 9117.010 & 1.000 \\
\hline \multirow{3}{*}{ Intercept } & $\mathrm{Y} 1$ & 2690.942 & 1 & 2690.942 & 2074615.324 & .000 & 1.000 & 2074615.324 & 1.000 \\
\hline & $\mathrm{Y} 2$ & 2777.047 & 1 & 2777.047 & 2179811.008 & .000 & 1.000 & 2179811.008 & 1.000 \\
\hline & $\mathrm{Y3}$ & 2834.363 & 1 & 2834.363 & 454907.969 & .000 & 1.000 & 454907.969 & 1.000 \\
\hline \multirow{3}{*}{$\mathrm{X}$} & $\mathrm{Y} 1$ & 1.451 & 24 & .060 & 46.596 & .000 & .902 & 1118.313 & 1.000 \\
\hline & $\mathrm{Y} 2$ & .712 & 24 & .030 & 23.287 & .000 & .822 & 558.899 & 1.000 \\
\hline & $\mathrm{Y3}$ & .896 & 24 & .037 & 5.990 & .000 & .543 & 143.759 & 1.000 \\
\hline \multirow{3}{*}{ Size } & $\mathrm{Y} 1$ & .211 & 4 & .053 & 40.717 & .000 & .574 & 162.869 & 1.000 \\
\hline & $\mathrm{Y} 2$ & .402 & 4 & .101 & 78.973 & .000 & .723 & 315.893 & 1.000 \\
\hline & $\mathrm{Y3}$ & .803 & 4 & 201 & 32.231 & .000 & .516 & 128.922 & 1.000 \\
\hline \multirow{3}{*}{ Gov } & $\mathrm{Y} 1$ & .149 & 10 & .015 & 11.521 & .000 & .488 & 115.209 & 1.000 \\
\hline & $\mathrm{Y} 2$ & .172 & 10 & .017 & 13.485 & .000 & .527 & 134.855 & 1.000 \\
\hline & $\mathrm{Y3}$ & .709 & 10 & .071 & 11.381 & .000 & .485 & 113.811 & 1.000 \\
\hline \multirow{3}{*}{ Own } & $\mathrm{Y} 1$ & .078 & 2 & .039 & 30.119 & .000 & .332 & 60.238 & 1.000 \\
\hline & $\mathrm{Y} 2$ & .052 & 2 & .026 & 20.328 & .000 & .251 & 40.655 & 1.000 \\
\hline & $\mathrm{Y} 3$ & .055 & 2 & .027 & 4.389 & .014 & .068 & 8.777 & .748 \\
\hline
\end{tabular}


Samra, Y.M.A. \& Elzahar, H. M.A. \& Fayed, H.M.A.

\section{Conclusion}

The objective of this study is to build on and extend the scope of recent and ongoing research on joint audit. While old wisdom suggests that two heads are better than one, empirical evidence on the impact of joint audit is inconclusive. We shed new insights into the joint audit literature by investigating the perceptions of professional auditors and academics about the impact of joint audit on the initial audit planning, the comprehensive audit strategy, and the overall audit plan and program, our proxy for audit planning quality. In order to achieve the main objective of the research and knowing the perceptions concerning the effects of joint audit on audit planning quality, we used questionnaires. Prior studies of joint audit focused on examining the impact of the joint audit on the final stages of the audit process, for instance (audit quality, financial reporting quality, and external auditor's report). The present research examines the effects of joint audit on the first stage of the audit, which is audit-planning quality.

We find that the majority of respondents prefer applying voluntary joint audit approach and appointing the two parties of joint audit, one of them is from Big 4 offices and the other from non-big 4 offices. We see that the voluntary joint audit gives freedom to companies to choose between single or joint audit according to the nature, characteristics of each company and the size of its business. In addition, the appointing one of the joint audit parties from Big 4 firms, helps companies to send good signals to the investors that they have distinct audits and the signature of a big 4 auditor on the audit report gives investors impression about the high level of trust, reliability, and governance for audits. While, appointing the other one from non-Big 4 firms helps to mitigate the audit market concentration.

The research findings show there is a positive relationship between joint audit and audit planning quality. It finds that the introduction of joint audit is considered as a useful mean of improving procedures during planning the audit, where it improves procedures during the initial audit planning, during the comprehensive audit strategy and during the overall audit plan and program. This can improve the audit quality as a whole, 
Scientific Journal for Financial and Commercial Studies and Researches

(SJFCSR) Faculty of Commerce - Damietta University

and adding confidence in the profession. Accordingly, European commission is advised to take this policy into consideration.

We conclude that joint audit has a positive impact on the initial audit planning by enhancing auditors' confidence regarding their decision whether accepting new client or continuing with the current by assessing the client's integrity and the client's business risk effectively. Ittonen \& Tronnes (2015); Bisogno \& De Luca (2016) indicated that companies whose management knows that its business is subject to audit by two independent auditors, will be more compliant with the various policies, procedures, and regulations, and more conservative in their earnings than companies audited by single auditor. Moreover, if the company's choice of the joint audit is voluntary, it provides an impression about the client's integrity, financial information and overall level of compliance (Lobo et al., 2017; Ibrahim, 2018). Abdelmoula \& Affes (2019) found the quality of the joint audit contributes to the prediction of three factors, namely competence, independence and reputation. Accordingly, joint audit provides greater opportunity for each existing audit firm to express any opposing opinions about the client objectively and without bias (Baldauf $\&$ Steckel, 2012). In addition, it provides a greater opportunity to select a more experienced and efficient staff than single audit (Holm \& Thinggaard, 2014; Velte, 2017).

Second, we further document that joint audit has a positive impact on the development of comprehensive audit strategy. Baldauf \& Steckel (2012); Zerni et al. (2012); Benali (2013); Deng et al. (2014); Okaro et al. (2018) documented that the participation of two audit firms in understanding the client's business and industry and assessing the audit risk enables auditors to develop an integrated audit plan and reduce the audit risk to the lowest acceptable level. This is due to each of the auditors has an area of internal specialization that may enable them to identify and assess the inherent risks and control risks accurately. Bianchi (2018) concluded that the cooperation of joint auditors in practicing audit tasks together enhances knowledge transfer and increases the experience of joint auditors. This can increase audit planning quality because if one of the auditors perceived that the procedures performed by the other auditor are inappropriate or insufficient, they can consult together to amend such procedures and take the necessary additional procedures 
Samra, Y.M.A. \& Elzahar, H. M.A. \& Fayed, H.M.A.

(Abdel-Hamid, 2014; El-Assy, 2015). Additionally, Youssef (2015) documented that the auditors' assessment of the fraud risks through the joint audit is more accurate than the auditors' assessment of these risks through the single audit. Third, we find that joint audit has a positive impact on the development of overall audit plan and program by increasing the level of coordination and cooperation among auditors, which enables them to develop an integrated audit plan and program (Abdel-Hamid, 2014; Alsadoun \& Aljabr, 2014).

The findings of this study have important implications for information users, auditors, and organizations, as well as for regulators. Evidence reported in this study that joint audit increases audit planning quality through its positive impact on the three stages of audit planning will provide assurance to organizations about the high level of audit quality as a whole and also to information users about the credibility of the financial statements audited by joint auditors. Hence, this will attract investors to invest in companies that have been audited by joint auditors and thus will create additional investment opportunities for these companies and increasing their stock prices. In addition, it will encourage audit firms to adopt the joint audit approach in order to maintain their reputation and reduce litigation risks. Hence, this will encourage regulators and professionals to issue a standard for joint audit that includes defining how to apply joint audit, principles and procedures that must be adhered by auditors and audit offices, in a manner that guarantees increased confidence in the audit profession in the Egyptian environment. Moreover, this will encourage academics to give an interest in teaching joint audit within auditing curricula in faculties of commerce in the Egyptian environment.

Future research might investigate the impact of joint audit on audit planning quality by using other indicators for instance, the audit firm size, industry specialization, and the audit fees. Finally, the empirical findings might encourage regulators to investigate the possibility of making joint audit voluntary for all companies and support small and mid-tier firms to acquire major clients, providing them with the experience, and allowing them to invest as needed to grow their presence in the large company market which leads to limit audit market concentration in Egypt. Future research might also conduct a 
Scientific Journal for Financial and Commercial Studies and Researches

(SJFCSR) Faculty of Commerce - Damietta University

comparative study about the impact of joint audit and audit planning quality in a developed country and a developing one or even between two developing countries and determining the differences and the reasons behind that would be interesting.

\section{References:}

Abdel-Halim, A. H. M. (2019). Measuring the impact of joint audit on the firm's value: Evidence from the Egyptian environment. Alexandria Journal of Accounting Research, 3(2), 159-235.

Abdel-Hamid, A. A. (2014). Joint Audit as a Tool of Increasing the Audit Quality: A Field Study. Egyptian Journal of Commercial Studies, 38(4), 165-219.

Abdelmoula, L., \& Affes, H. (2019). Determining Factors of the Quality of Joint Audit: Tunisian Context. Accounting and Management Information Systems, 18(4), 559-587.

Abdel-Qawi, A. S. H. (2017). The Impact of Joint Audit on the External Auditor's Report: Analytical Study. Unpublished Master Thesis, Assiut University, 1-195.

ACCA. (2011). Audit under Fire: A Review of the Post-Financial Crisis Inquiries. Report by the Association of Chartered Certified Accountants. London: ACCA.

Alanezi, F., Alfaraih, M., Alrashaid, E., \& Albolushi, S. (2012). Dual/Joint Auditors and the Level of Compliance with International Financial Reporting Standards (IFRS-Required Disclosure). Journal of Economic and Administrative Sciences, 28(2), 109-129.

Alfraih, M. (2016). Corporate Governance Mechanisms and Audit Delay in a Joint Audit Regulation. Journal of Financial Regulation and Compliance, 24(3), 292-316.

Al-Hadi, A., Habib, A., Al-Yahyaee, K., \& Eulaiwi, B. (2017). Joint Audit, Political Connections and Cost of Debt Capital. International Journal of Auditing, 21(3), 249-270.

Ali, E. Z. A. (2019). Determinants of demand for joint audit: An applied study to determine the characteristics of the joint audit client in the 
Samra, Y.M.A. \& Elzahar, H. M.A. \& Fayed, H.M.A.

Egyptian environment. Egyptian Journal of Business Studies, 34(1), 148-188.

Alsadoun, N., \& Aljabr, Y. (2014). Joint Audit and Cost of Equity Capital: Evidence from Saudi Arabia. Forthcoming. Journal of King Abdul-Aziz University: Economics and Administration, 1(33), $1-35$.

American Institute of Certified Public Accountants. (2017). AU Section 315: Communications between Predecessor and Successor Auditors. New York, NY: AICPA.

Audousset-Coulier, S. (2014). Audit Fees in a Joint Audit Setting. European Accounting Review, 24(2), 347-377.

Backof, A. G., Martin, R. D., \& Thayer, J. M. 2018. How do Look-Back Analyses and Evidence Specificity affect Auditors' Planning Judgments? Working paper, University of Virginia.

Baldauf, J., \& Steckel, R. (2012). Joint Audit and Accuracy of the Auditor's Report: An Empirical Study. International Journal of Economic Sciences and Applied Research, 5(2), 7-42.

Barghathi, Y., Ndiweni, E., \& Lasyoud, A. A. (2020). Joint Audit, Audit Market Concentration, and Audit Quality: Perceptions of Stakeholders in the UAE. Corporate Ownership and Control, 17(2), 32-45.

Bédard, J., Piot, C., \& Schatt, A. (2014). An Evaluation of the French Experience with Joint Auditing. Working Paper, 1-49, Available at: http://dx.doi.org/10.2139/ssrn.2165595.

Benali, A. (2013). The Shareholders Confidence and Effectiveness of the Joint Auditors: Empirical Validation in the French Context. International Journal of Business and Management, 8(11), 76-84.

Bianchi, P. A. (2018). Auditors' Joint Engagements and Audit Quality: Evidence from Italian Private Companies. Contemporary Accounting Research, 35(3), 1533-1577.

Bisogno, M., \& De. Luca, R. (2016). Voluntary Joint Audit and Earnings Quality: Evidence from Italian SMEs. International Journal of Business Research and Development, 5(1), 1-22. 
Scientific Journal for Financial and Commercial Studies and Researches (SJFCSR) Faculty of Commerce - Damietta University

Burke, A. (2015). Introduction to Audit Planning, Examiner Professional Auditing. Retrieved from: http://www.cpaireland.ie/docs/defaultsource/Students/Study-Support/P1-Auditing/introduction-to-audit planning.pdf ?sfvrsn. (Accessed 24/1/2019).

Deng, M., Lu, T., Simunic, D. A., \& Ye, M. (2014). Do Joint Audits Improve or Impair Audit Quality? Journal of Accounting Research, 52(5), 1029-1060.

El-Assy, M. G. M. (2015). Studying and Testing the Effect of Joint Audit Approach on the Quality of Auditing and Financial Reports of listed Companies in the Stock Exchange. Unpublished Master Thesis, Alexandria University, 1-145.

El-Siddiq, E. A. (2015). Factors Affecting the Auditor's Performance of Risks for the Purposes of Audit Planning: An Empirical Study by Applying to the National Audit Office and the Accounting and Auditing Profession Regulatory Council. Unpublished Master Thesis, Omdurman Islamic University, Jordan, 1-210.

European Commission (EC). (2010). Green Paper: Audit Policy: Lessons from the Crisis. Brussels, Belgium.

European Commission (EC). (2011b). Restoring Confidence in Financial Statements: The European Commission Aims at a Higher Quality. Dynamic and Open Audit Market, Brussels, Belgium.

Fan, Y., Li, C., Nagarajan, N., \& Smith, J. (2015). Auditor Litigation, Audit Office Pricing and Client Acceptance. Working paper, University of Pittsburgh, Texas A \&M University and 2015 Midyear Auditing Conference.

Fernando, G. D., Abdel - Meguid, A. M., \& Elder, R. J. (2010). Audit Quality Attributes, Client Size and Cost of Equity Capital. Review of Accounting and Finance, 9(4), 363-381.

Francis, J. R., Richard, C., \& Vanstraelen, A. (2009). Assessing France's Joint Audit Requirement: Are Two Heads Better than One? Auditing: A Journal of Practice \& Theory, 28(2), 35-63. 
Samra, Y.M.A. \& Elzahar, H. M.A. \& Fayed, H.M.A.

Galy, A. A. M. (2018). Measuring the Impact of Joint Audit on the relationship between the accounting conservatism and firm value. Journal of Accounting Thought, 22(4), 1230-1300.

Gliem, J. A. \& Gliem, R. R. (2003). Calculating, interpreting, and reporting Cronbach "s alpha reliability coefficient for Likert-type scales, Midwest Research-to-Practice Conference in Adult, Continuing, and Community Education.

Gray, L., \& Manso, S. (2005). The Audit Process, Principles, Practices, and Cases. Thomson Learning, $3^{\text {rd }}$ ED: London. Available at: https://books.google.com.eg/books?hl=ar\&lr=\&id=NwPRL6QVr9E $\underline{\mathrm{C} \& o \mathrm{i}=\text { fnd \&pg }=\mathrm{PR} 14 \& \mathrm{dq}=\text { the }+ \text { audit }+ \text { process },+ \text { principles },+ \text { practice }}$ s, +and+cases. Accessed: (26/7/2019)

Haak, M., Muraz, M., \& Zieseniß, R. (2018). Joint Audits: Does the Allocation of Audit Work Affect Audit Quality and Audit Fees? Accounting in Europe, 1- 26.

Hair. Jr, Black, Babin, and Anderson. (2010). Multivariate Data Analysis, 7th Edition, Pearson Prentice Hall.

Hassoubh, K. M. A. (2017). The Impact of the Client Practices to Mislead External Auditor on the Audit Planning Quality: A Field Study. Unpublished PhD Thesis, Cairo University.

Holm, C., \& Thinggaard, F. (2014). Leaving a Joint Audit System: Conditional Fee Reductions. Managerial Auditing Journal, 29(2), 131-152.

Ibrahim, N. S. (2018). The Impact of Appling Joint Audit on Earnings Quality and Firm's Value: An Empirical Study. Unpublished Master Thesis, Cairo University, 1-160.

International Auditing and Assurance Standards Board (IAASB). (2017). International Standard on Auditing No. 300: Planning an Audit of Financial Statements. New York, NY: IFAC.

Ittonen, K., \& Peni, E. (2012). Auditor's Gender and Audit Fees. The International Journal of Auditing, 16(1), 1-18. 
Scientific Journal for Financial and Commercial Studies and Researches (SJFCSR) Faculty of Commerce - Damietta University

Ittonen, K., \& Trønnes, P. C. (2015). Benefits and Costs of Appointing Joint Audit Engagement Partners. Auditing: A Journal of Practice \& Theory, 34(3), 23-46.

Johnstone, K. M., \& Bedard, J. C. (2003). Risk Management in Client Acceptance Decisions. The Accounting Review, 78(4), 1003-1025.

Kermiche, L., \& Piot, C. (2018). The Audit Market Dynamics in a Mandatory Joint Audit Setting: The French Experience. Journal of Accounting, Auditing \& Finance, 33(4), 463-484.

Laux, V., \& Newman, D. P. (2010). Auditor Liability and Client Acceptance Decisions. The Accounting Review, 85(1), 261-285.

Lesage, C., Ratzinger-Sakel, N. V. S., \& Kettunen, J. (2012). Struggle over Joint Audit: on Behalf of Public Interest? Available at: https://papers.ssrn.com/404.cfm?404; http://papers.ssrn.com:80/abst ract $\% \mathrm{C} 2 \% \mathrm{BC} 2176729$.

Lin, Z. K., \& Fraser, I. A. (2003). The Use of Analytical Procedures by External Auditors in Canada. Journal of International Accounting Auditing \& Taxation, 12(2), 153-168.

Lin, C. J., Lin, H. L., \& Yen, A. R. (2014). Dual Audit, Audit Firm Independence, and Auditor Conservatism. Review of Accounting and Finance, 13(1), 65-87.

Lobo, G., Paugam, L., Zhang, L., \& Casta, J-F. (2014). Effect of Joint Auditor Pair on Conservatism: Evidence from Impairment Tests. Available at: https://hal.archives-ouvertes.fr/hal-00993007. (Accessed: 9/10/2018).

Lobo, G., Paugam, L., Zhang, L., \& Casta, J-F. (2017). The Effect of Joint Auditor Pair Composition on Audit Quality: Evidence from Impairment Tests. Contemporary Accounting Research, 34(1), 118-153.

Mahmoud, H. S. (2020). A proposed model for measuring the effects of differentiation factors between both single and joint audit on the decision of audit committee about the choice of external auditor. Scientific Journal of Economics and Commerce, 35-116. 
Samra, Y.M.A. \& Elzahar, H. M.A. \& Fayed, H.M.A.

Mahmoud, M. O. A. (2017). Studying the Impact of Joint Audit on the Quality and Fees of the Audit. Unpublished Master Thesis, Cairo University, 1-172.

Marnet, O., Barone, E., \& Gwilliam, D. (2018). Joint Audit - a Means to Reduce Bias and Enhance Scepticism in Financial Statement Audits? Electronic copy available at: https://ssrn.com/abstract $=3300117$.

Mitchell, M. \& Jolley, J. (2012). Research design explained. Stamford, CT: Cengage Learning.

Moody, C. (2009). Basic econometrics with stats. Economics Department, College of William and Mary.

Okaro, S. C., Okafor,G. O., \& Ofoegbu, G. N. (2018). Mandating Joint Audits in Nigeria: Perspectives and Issues. International Journal of Academic Research in Business and Social Sciences, 8(3), 316338.

Paugam, L., \& Casta, J.-F. (2012). Joint Audit, Game Theory, and Impairment Testing Disclosures, Available at: http://papers.ssrn.com/sol3/papers.cfm?abstract id=1985541.

Peecher, M. E., Schwartz, R., \& Solomon, I. (2007). It is all about audit quality: Perspectives on strategic-systems auditing. Accounting, Organizations and Society, 32(4-5), 463-485.

Phagaphasvivat, S. (2000). Strategic Management. Bangkok, Amerin.

Piot, C. (2007). Auditor Concentration in a Joint Auditing Environment: the French Market. Managerial Auditing Journal, 22(2), 161-176.

Quick, R., \& Schmidt, F. (2018). Do Audit Firm Rotation, Auditor Retention, and Joint Audits Matter? An Experimental Investigation of Bank Directors' and Institutional Investors' Perceptions. Journal of Accounting Literature, 41, 1-21.

Ratanasongtham, W., \& Ussahawanitchakit, P. (2015), Strategic Audit Planning and Audit Quality: An Empirical Research of CPAs in Thailand. The Business and Management Review, 7(1), 384- 394. 
Scientific Journal for Financial and Commercial Studies and Researches (SJFCSR) Faculty of Commerce - Damietta University

Ratzinger-Sakel, N., Audousset-Coulier, S., Kettunen, J., \& Lesage, C. (2013). Joint Audit: Issues and Challenges for Researchers and Policy-Makers. Accounting in Europe, 10(2), 175-199.

Ruwished, M. G. (2016). The Impact of Joint Audit on Audit Quality and Fees: An Applied Study. The 11th International Scientific Conference: Financial and Banking Transitions, Reality and Future Prospects, Zurqa, Jordan, 4-5 May, 1-43.

Sakr, Y. A. A. (2018). A Proposed Framework for Measuring the Relationship between Audit Quality and the Requirements of Strategic Auditing Planning: A Field Study. Unpublished Ph.D Thesis, Ain Shams University, 1-255.

Saleh, A. M. (2015). The Impact of Joint Audit on Audit Quality and Audit Market Concentration in the Egyptian Environment. 29(2), 71-102.

Velte, P. (2017). What Do We Know About Empirical Joint Audit Research? A Literature Review. Accounting and Financial Control, $1(1), 4-14$.

Youssef, H. M. I. (2015). The Impact of the Activation of Joint Audit on the Efficiency of the Auditor in the Detecting and Reporting on the Fraud in the Financial Statements. Journal of Accounting Thought, 19(2), 437-504.

Zerni, M., Haapamäki, E., Järvinen, T., \& Niemi, L. (2012). Do Joint Audits Improve Audit Quality? Evidence from Voluntary Joint Audits. European Accounting Review, 21(4), 731-765. 
Samra, Y.M.A. \& Elzahar, H. M.A. \& Fayed, H.M.A.

\section{Appendix:}

Descriptive statistics for control variables

\begin{tabular}{|c|c|c|c|c|c|}
\hline \multicolumn{6}{|c|}{ Panel A: Client's size (S) } \\
\hline & Question & Mean & $\begin{array}{c}\text { Std. } \\
\text { Deviation }\end{array}$ & $\begin{array}{c}\text { Cof. } \\
\text { Variation }\end{array}$ & Rank \\
\hline Q 1 & $\begin{array}{l}\text { The multiplicity of activities } \\
\text { and complexity of tasks. }\end{array}$ & 4.42 & 0.59 & $13.35 \%$ & 1 \\
\hline Q 2 & $\begin{array}{l}\text { Increasing the aggressive } \\
\text { accounting practices. }\end{array}$ & 4.33 & 0.64 & $14.78 \%$ & 2 \\
\hline Q 3 & Increasing agency conflicts. & 4.31 & 0.64 & $14.85 \%$ & 5 \\
\hline Q 4 & Increasing agency costs. & 4.31 & 0.62 & $14.39 \%$ & 4 \\
\hline Q 5 & $\begin{array}{l}\text { The difficulty of determining } \\
\text { the effectiveness of controlling } \\
\text { internal operations. }\end{array}$ & 4.14 & 0.75 & $18.12 \%$ & 6 \\
\hline Q 6 & $\begin{array}{l}\text { The difficulty of determining } \\
\text { the efficiency of controlling } \\
\text { internal operations. }\end{array}$ & 4.32 & 0.62 & $14.35 \%$ & 3 \\
\hline & Average & 4.305 & 0.643 & $14.94 \%$ & \\
\hline \multicolumn{6}{|c|}{ Panel B: Corporate governance (G) } \\
\hline Q 1 & $\begin{array}{l}\text { A lower degree of risks } \\
\text { associated with auditing the } \\
\text { financial statements. }\end{array}$ & 4.37 & 0.59 & $13.50 \%$ & 7 \\
\hline Q 2 & \begin{tabular}{lrr} 
The & \multicolumn{2}{c}{ management's } \\
commitment & to & set \\
appropriate strategic & goals \\
and general policies & that \\
dominate the workflow. & \\
\end{tabular} & 4.44 & 0.60 & $13.51 \%$ & 2 \\
\hline Q 3 & $\begin{array}{l}\text { The management's } \\
\text { commitment to implement its } \\
\text { supervisory responsibilities } \\
\text { effectively. }\end{array}$ & 4.32 & 0.61 & $14.12 \%$ & 11 \\
\hline Q 4 & $\begin{array}{l}\text { The Board of Directors } \\
\text { choosing the best way to } \\
\text { implement governance and }\end{array}$ & 4.33 & 0.64 & $14.78 \%$ & 10 \\
\hline
\end{tabular}


Scientific Journal for Financial and Commercial Studies and Researches (SJFCSR) Faculty of Commerce - Damietta University

\begin{tabular}{|c|c|c|c|c|c|}
\hline \multicolumn{6}{|c|}{ Panel A: Client's size (S) } \\
\hline & Question & \multirow[t]{2}{*}{ Mean } & \multirow[t]{2}{*}{$\begin{array}{c}\text { Std. } \\
\text { Deviation } \\
\end{array}$} & \multirow[t]{2}{*}{$\begin{array}{c}\text { Cof. } \\
\text { Variation } \\
\end{array}$} & \multirow[t]{2}{*}{ Rank } \\
\hline & $\begin{array}{l}\text { adopting the professional } \\
\text { standards that employees must } \\
\text { follow. }\end{array}$ & & & & \\
\hline Q 5 & $\begin{array}{l}\text { Increasing the independence } \\
\text { level of the Board of Directors. }\end{array}$ & 4.11 & 0.74 & $18.00 \%$ & 13 \\
\hline Q 6 & $\begin{array}{l}\text { Increasing the independence } \\
\text { level of the audit committees. }\end{array}$ & 4.34 & 0.64 & $14.75 \%$ & 8 \\
\hline Q 7 & $\begin{array}{l}\text { The audit committees are } \\
\text { more committed to study the } \\
\text { company's internal control } \\
\text { system effectively. }\end{array}$ & 4.41 & 0.61 & $13.83 \%$ & 3 \\
\hline Q 8 & $\begin{array}{l}\text { The board of directors are } \\
\text { more committed in } \\
\text { investigating the accuracy } \\
\text { when selecting the members of } \\
\text { the audit committee from } \\
\text { those with financial and } \\
\text { accounting experience. }\end{array}$ & 4.50 & 0.62 & $13.78 \%$ & 1 \\
\hline Q 9 & $\begin{array}{l}\text { The audit committee supports } \\
\text { auditors independence and } \\
\text { provides them with the } \\
\text { information and clarifications } \\
\text { they need. }\end{array}$ & 4.38 & 0.66 & $15.07 \%$ & 4 \\
\hline Q 10 & $\begin{array}{l}\text { The availability of quality } \\
\text { characteristics in both the } \\
\text { board of directors and the } \\
\text { audit committee. }\end{array}$ & 4.38 & 0.70 & $15.98 \%$ & 5 \\
\hline Q 11 & $\begin{array}{l}\text { Internal auditors are more } \\
\text { committed to perform their } \\
\text { duties effectively, in particular } \\
\text { their role in evaluating the } \\
\text { effectiveness of internal } \\
\text { control system. }\end{array}$ & 4.37 & 0.53 & $12.13 \%$ & 6 \\
\hline Q 12 & $\begin{array}{l}\text { Increasing the internal } \\
\text { auditors' motivation to ensure }\end{array}$ & 4.33 & 0.61 & $14.09 \%$ & 9 \\
\hline
\end{tabular}


Samra, Y.M.A. \& Elzahar, H. M.A. \& Fayed, H.M.A.

\begin{tabular}{|c|c|c|c|c|c|}
\hline \multicolumn{6}{|c|}{ Panel A: Client's size (S) } \\
\hline & Question & Mean & $\begin{array}{c}\text { Std. } \\
\text { Deviation }\end{array}$ & $\begin{array}{c}\text { Cof. } \\
\text { Variation }\end{array}$ & Rank \\
\hline & $\begin{array}{l}\text { the proper application of } \\
\text { corporate governance rules. }\end{array}$ & & & & \\
\hline \multirow[t]{2}{*}{ Q13 } & $\begin{array}{l}\text { Internal auditors are more } \\
\text { transparent when assisting the } \\
\text { external auditor in } \\
\text { understanding the internal } \\
\text { control system or performing } \\
\text { verification tests. }\end{array}$ & 4.29 & 0.65 & $15.15 \%$ & 12 \\
\hline & Average & 4.351 & 0.6307 & $14.50 \%$ & \\
\hline \multicolumn{6}{|c|}{ Panel C: Institutional ownership (O) } \\
\hline Q 1 & $\begin{array}{l}\text { Preventing the board of } \\
\text { directors from adopting } \\
\text { opportunistic behaviors that } \\
\text { conflict with the interests of } \\
\text { other shareholders. }\end{array}$ & 4.34 & 0.66 & $15.21 \%$ & 3 \\
\hline Q 2 & $\begin{array}{l}\text { Reducing the abuse of } \\
\text { administrative immunity. }\end{array}$ & 4.35 & 0.65 & $14.94 \%$ & 2 \\
\hline Q 3 & $\begin{array}{l}\text { Increasing managers' } \\
\text { submission to supervision and } \\
\text { control. }\end{array}$ & 4.29 & 0.72 & $16.78 \%$ & 6 \\
\hline Q 4 & $\begin{array}{l}\text { Increasing company's } \\
\text { management interest in } \\
\text { activating the controlling } \\
\text { governance mechanisms. }\end{array}$ & 4.37 & 0.68 & $15.56 \%$ & 1 \\
\hline Q 5 & $\begin{array}{l}\text { Increasing company's } \\
\text { management interest in } \\
\text { activating the controlling role } \\
\text { of the audit committee. }\end{array}$ & 4.30 & 0.65 & $15.12 \%$ & 4 \\
\hline Q 6 & $\begin{array}{l}\text { The owners' keenness to } \\
\text { achieve the highest possible } \\
\text { quality of audit planning. }\end{array}$ & 4.29 & 0.64 & $14.92 \%$ & 5 \\
\hline & Average & 4.323 & 0.67 & $15.42 \%$ & \\
\hline
\end{tabular}


Scientific Journal for Financial and Commercial Studies and Researches (SJFCSR) Faculty of Commerce - Damietta University

\begin{tabular}{|c|c|c|c|c|c|}
\hline \multicolumn{6}{|c|}{ Pearson Correlations Coefficients of all questions (control variables) } \\
\hline \multicolumn{2}{|c|}{ Size } & \multicolumn{2}{|c|}{ Governance } & \multicolumn{2}{|c|}{ Institutional Ownership } \\
\hline Question & $\mathbf{R}$ & Question & $\mathbf{R}$ & Question & $\mathbf{R}$ \\
\hline Q1 & $0.691 * *$ & Q1 & $0.732 * *$ & Q1 & $0.687^{* *}$ \\
\hline Q2 & $0.722 * *$ & Q2 & $0.654 * *$ & Q2 & $0.729 * *$ \\
\hline Q3 & $0.769 * *$ & Q3 & $0.710^{* *}$ & Q3 & $0.819^{* *}$ \\
\hline Q4 & $0.738^{* *}$ & Q4 & $0.759 * *$ & Q4 & $0.850^{* *}$ \\
\hline Q5 & $0.669^{* *}$ & Q5 & $0.670^{* *}$ & Q5 & $0.795^{* *}$ \\
\hline Q6 & 0.708 & Q6 & $0.775^{* *}$ & Q6 & $0.754 * *$ \\
\hline & & Q7 & $0.740 * *$ & & \\
\hline & & Q8 & $0.731^{* *}$ & & \\
\hline & & Q9 & $0.833^{* *}$ & & \\
\hline & & Q10 & $0.793 * *$ & & \\
\hline & & Q11 & $0.694^{* *}$ & & \\
\hline & & Q12 & $0.741 * *$ & & \\
\hline & & Q13 & $0.757^{* *}$ & & \\
\hline
\end{tabular}


Samra, Y.M.A. \& Elzahar, H. M.A. \& Fayed, H.M.A.

أثرالمراجعت المشتركتمعلى جودة تخطيط المراجعت: دراستميدانيت

د. ياسر محمد عبد العزيز سمره؛ د. هانئ محمد عزيز الزهار؛ أ. هدير مسعد أحمد فايد

\section{الملخص:}

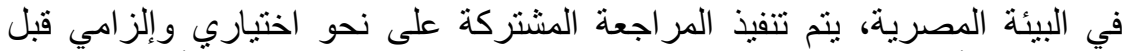

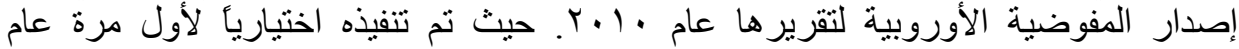

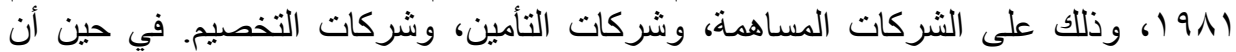

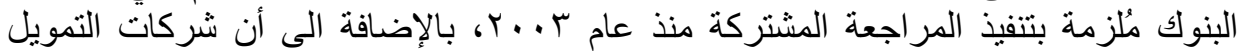

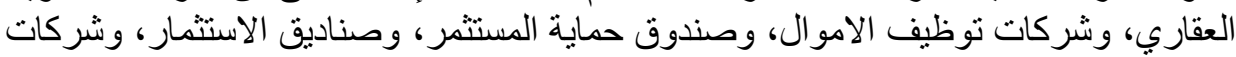

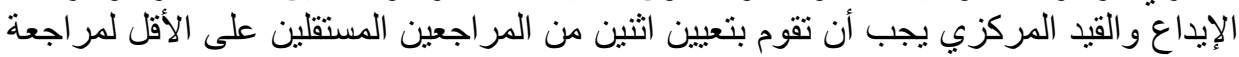

حساباتها.

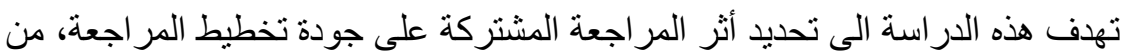

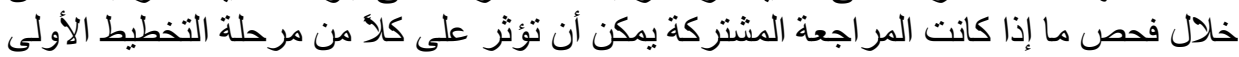

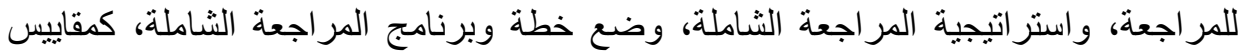

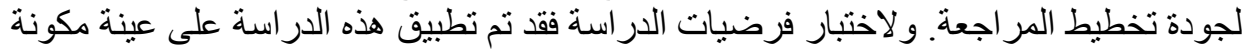

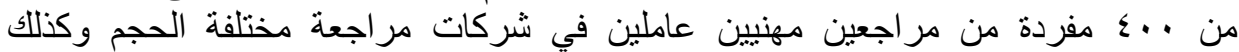

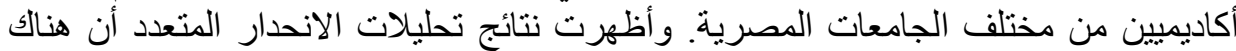

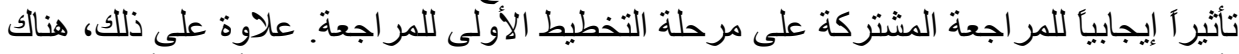

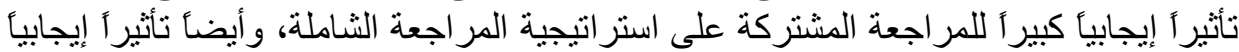

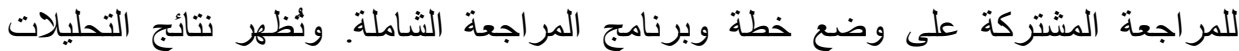

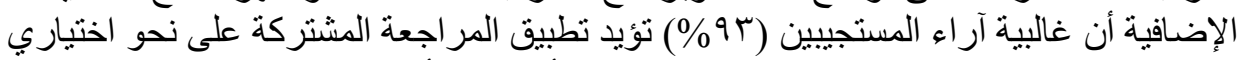

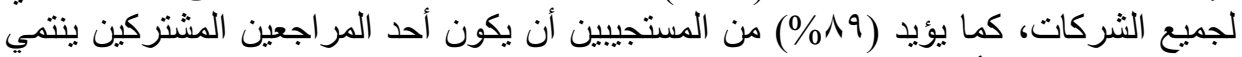

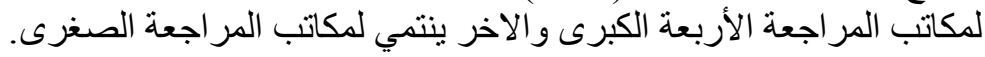

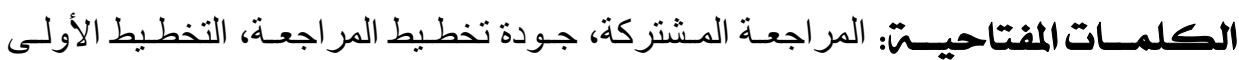

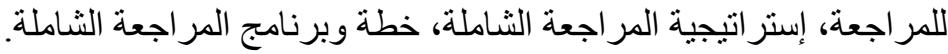

